\title{
Spectral, Thermal and Antibacterial Studies for Bivalent Metal Complexes of Oxalyl, Malonyl and Succinyl-bis-4- phenylthiosemicarbazide Ligands
}

\author{
Ragab R. Amin1*, Ahmed A. M. El-Reedy², Tajedin Y. Alansi'3 ${ }^{3}$ Yamany B. Yamany ${ }^{4}$ \\ ${ }^{1}$ Basic Science Department, Faculty of Engineering, Nahda University, Beni-Suef, Egypt \\ ${ }^{2}$ Basic and Applied Science Department, Faculty of Oral and Dental Medicine, Nahda University, Beni-Suef, \\ Egypt \\ ${ }^{3}$ Chemistry Department, Adama Science and Technology University, Adama, Ethiopia \\ ${ }^{4}$ Pharmaceutical Chemistry Department, Faculty of Pharmacy, Taif University, Taif, Saudia Arabia \\ Email:"rramin2010@.yahoo.com, Ahmed.reedy78@gmail.com
}

Received 16 November 2015; accepted 19 February 2016; published 22 February 2016

Copyright (C) 2016 by authors and Scientific Research Publishing Inc.

This work is licensed under the Creative Commons Attribution International License (CC BY).

http://creativecommons.org/licenses/by/4.0/

(c) (i) Open Access

\begin{abstract}
The thermogravimetry (TG) and derivative thermogravimetry (DTG) have been used to study the thermal decomposition of some oxalyl ( $\mathrm{H}_{4} \mathrm{OxTSC}$ ), malonyl ( $\mathrm{H}_{4} \mathrm{MaTSC}$ ) and succinyl-bis-4-phenylthiosemicarbazide $\left(\mathrm{H}_{4} \mathrm{SuTSC}\right)$ ligands and their metal complexes using Horowitz-Metzger (HM) and Coats-Redfern methods. The kinetic thermodynamic parameters such as: $\mathrm{E}^{*}, \Delta \mathrm{H}^{*}, \Delta \mathrm{S}^{*}$ and $\Delta \mathrm{G}^{*}$ are calculated from the DTG curves. The isolated complexes have the general composition $\left[\mathrm{M}_{2}(\mathrm{~L})\right.$ $\left(\mathrm{H}_{2} \mathrm{O}\right)_{6}$ ], where $\mathrm{M}=\mathrm{Cu}(\mathrm{II}), \mathrm{Zn}(\mathrm{II}), \mathrm{L}=\mathrm{MaTSC}$ and $\mathrm{M}=\mathrm{Co}(\mathrm{II}), \mathrm{Cu}(\mathrm{II})$ or $\mathrm{Sn}$ (II) and $\mathrm{L}=\mathrm{Su}$ TSC and [M $\mathrm{M}_{2}(\mathrm{~L})$ $\left.\left(\mathrm{H}_{2} \mathrm{O}\right)_{\mathrm{n}}\right] \cdot \mathrm{nH}_{2} \mathrm{O}$ where $\mathrm{M}=\mathrm{Cu}(\mathrm{II}), \mathrm{Co}(\mathrm{II})$ or $\mathrm{Sn}(\mathrm{II}), \mathrm{L}=\mathrm{OxTS}$ or Ma TSC. The tested compounds show a good activity against four strains of bacteria Gram negative Escherichia coli, Pseudomonas aeruginosa species and gram-positive Bacillus cereus and Staphylococcus aureus.
\end{abstract}

\section{Keywords}

Metal (II) Complexes, Bis-Thiosemicarbazide, Thermogravimetric, Antibacterial Studies

\section{Introduction}

Thiosemicarbazide and its derivatives have received considerable attention because of their pharamacological

\footnotetext{
${ }^{*}$ Corresponding author.
}

How to cite this paper: Amin, R.R., El-Reedy, A.A.M., Alansi, T.Y. and Yamany, Y.B. (2016) Spectral, Thermal and Antibacterial Studies for Bivalent Metal Complexes of Oxalyl, Malonyl and Succinyl-bis-4-phenylthiosemicarbazide Ligands. Open Journal of Inorganic Chemistry, 6, 89-113. http://dx.doi.org/10.4236/ojic.2016.62006 
properties [1]. Thiosemicarbazide complexes show a broad spectrum of anticancer activity [2] [3]. Also, thiosemicarbazide derivatives are of current interest with respect to their uses as analytical reagents for separations of metal(II) ions [4]-[7], analytical determination of metal ions [8] [9], and clinical analysis [10]. Most of these compounds have antifungal [11]-[12], antimicrobial [13] and antitumor activity [14]-[16], as well as radiopharmaceuticals applications [17]. Continuing our studies for the chemical and electrochemical synthesis of new metal complexes of ligands containing $\mathrm{N}, \mathrm{S}$ and $\mathrm{O}$ atoms through the reaction of metal ions scarified from the anodic dissolution of metals [18] [19]. Our aim work in this paper to report novel complexes prepared from the reaction between bisthiosemicarbazi decompounds which have a good ability to form chelate complexes with transition metal [18]-[20]. We report here the thermal, spectral and biological evaluations of $\mathrm{Co}(\mathrm{II}), \mathrm{Cu}(\mathrm{II})$, Zn(II) and Sn(II) complexes for 1,1-oxalyl, malonyl and succinyl-bis-4-phenylthiosemicarbazide ligands. The modern spectroscopic investigations are used to elucidate the structure of the prepared materials. The thermal decomposition is also used to infer the structure of the metal complexes and to calculate the different thermodynamic activation parameters.

\section{Experimental}

\subsection{The Organic Compounds}

1) Preparation of 1,1-Oxalylhydrazide: 1,1-oxalyldihydrazine was prepared by adding oxalyl chloride (7 gm, $0.05 \mathrm{~mol}$ ) to alcoholic solution of hydrazine hydrate ( $5 \mathrm{gm}, 0.1 \mathrm{~mole}$ ). The reaction mixture was exothermic and left to cool with stirring. A white crystal precipitate was formed and washed with ethanol diethyl ether and left to dry.

2) Preparation of 1,1-Oxalylbis (4-phenylthiosemicarbazide): It was prepared by adding phenylisothiocynate (2.8 gm, $0.02 \mathrm{~mol}$ ) to an alcoholic solution of oxalic acid dihydrazide (1.18 gm, 0.01 mole). The reaction mixture was refluxed for 1 hour and left to cool with stirring. The resulting white crystals were collected and washed with ethanol and diethyl ether, respectively. The resulting solids were filtered hot, washed with hot dist. water, $\mathrm{EtOH}$ and dried by $\mathrm{Et}_{2} \mathrm{O}$ and finally dried in vacuum over silica gel (Figure 1).

3) Preparation of 1,1-Malonylbis-phenylthiosemicarbazide: 1,1-Malonyl bis-4-phenylthiosemicarbazide) was prepared by adding phenylisothiocynate $(1.8 \mathrm{gm}, 0.02 \mathrm{~mol})$ to an alcoholic solution of malonic acid dihydrazide ( $1.32 \mathrm{gm} \approx 0.01$ mole). The reaction mixture was refluxed for 1 hour and left to cool with stirring. The resulting white crystals were collected and washed with ethanol and diethyl ether, respectively. The resulting solids were filtered hot, washed with hot dist. water, $\mathrm{EtOH}$ and dried by $\mathrm{Et}_{2} \mathrm{O}$ and finally dried in vacuo over silica gel.

4) Preparation of 1,1-Succinylbis-4-phenylthiosemicarbazide: It was prepared by the same way [20]-[21].

\subsection{The In-Organic Compounds}

The preparative results show that the direct electrochemical oxidation of the metals in the presence of a ligand solution is a one-step process and represents a convenient and simple route to a variety of transition metal complexes. The apparatus used in the electrochemical reaction consists of a tall-form $100 \mathrm{~mL}$ Pyrex beaker containing $50 \mathrm{~mL}$ of the appropriate amount of the organic ligand dissolved in acetone solution. The cathode is a platinum wire of approximately $1 \mathrm{~mm}$ diameter. In most cases, the metal (2 - $5 \mathrm{~g})$ was suspended and supported on a platinum wire. Measurements of the electrochemical efficiency, Ef, defined as moles of metal dissolved per Faraday of electricity, for the $\mathrm{M} / \mathrm{L}$ system (where $\mathrm{L}=$ ligand used) gave $\mathrm{E}_{\mathrm{f}}=0.5 \pm 0.05 \mathrm{~mol} \cdot \mathrm{F}^{-1}$.

\subsection{Synthesis of Metals Complexes}

Electrolysis of cobalt metal into $60 \mathrm{ml}$ of anhydrous acetone solution of 1,1-oxalaylbis (4-phenylthiosemi-carbazide)ligand as an example, (1.2 gm, $5 \mathrm{mmol}), 0.5 \mathrm{mg} \mathrm{Et}_{4} \mathrm{NClO}_{4}$ dissolved in two drops of water and $20 \mathrm{~V}$ current led to dissolution of $116 \mathrm{mg}$ of Co during $120 \mathrm{~min}$. $\left(\mathrm{E}_{\mathrm{f}}=0.5 \mathrm{~mol} \cdot \mathrm{F}^{-1}\right)$. Since, most of the products are insoluble in the reaction mixture, the collection procedure involved filtration, after which the solid was washed with diethyl ether. The resulting green powder was collected. By the same way $\mathrm{Cu}, \mathrm{Zn}$, and $\mathrm{Sn}$ complexes were isolated and all the data for carbon, hydrogen and nitrogen were gathered in Table 1.

\section{Spectral, Analytical and Physical Measurements}

\subsection{IR, Raman and $1 \mathrm{H}-\mathrm{NMR}$ Spectra}

Infrared spectra for the three ligands and their metal complexes were recorded by Perkin Elmer FTIR 1605 using 
KBr pellets (Figures S1-S3). Also, Raman spectra for the ligands, Zinc(II) and Sn(II) metal complexes were recorded in the solid state on Thero Nicolet FT-Raman (USA) with a wavelength $1064 \mathrm{~nm}$ power according sample resolution was $8 \mathrm{~cm}^{-1}$ at National Research Center, Cairo, Egypt (Figures S4-S6). The ${ }^{1} \mathrm{H}$ NMR spectra were recorded on an Varian Mercury VX-300 NMR spectrometer. ${ }^{1} \mathrm{H}-\mathrm{NMR}$ spectra were run at $300 \mathrm{MHz}$ and ${ }^{13} \mathrm{C}-\mathrm{NMRspectra}$ were run at $75.46 \mathrm{MHz}$ in deuterated dimethylsulphoxide (DMSO- $\mathrm{d}_{6}$ ).

\subsection{Electronic and Mass Spectra}

The electronic spectra for all the ligands and the metal complexes solutions were measured in UV/Vis range (190 - 1100) nm using Helios UV Spectrometer at Center Photo energy, Ain-Shams University. Mass spectra were recorded at SHIMADZU GC MS-QP 1000 EX Micro analytical Center, Cairo Universal, Giza and AlAzher University, Egypt (Figures S7-S9).

\subsection{Magnetic Molar Conductance Measurements}

Magnetic measurements were carried out on a Sherwood scientific magnetic balance using Gouy method. Molar conductivities of freshly prepared $1.0 \times 10^{-3} \mathrm{~mol} \cdot \mathrm{L}^{-1}$ DMSO solutions were measured using Jenway 4010 conductivity meter.

\subsection{Microanalytical and Magnetic Measurements}

Carbon and hydrogen contents were determined using a Perkin-Elmer CHN 2400 analyser. Magnetic measurements were carried out on a Sherwood scientific magnetic balance using Gouy method.

Table 1. Significant IR spectral bands $\left(\mathrm{cm}^{-1}\right)$ of the ligand of 1,1-oxalyl-, malonyl, succinylbis-4-phenylthiosemicarbazide and their metal complexes.

\begin{tabular}{|c|c|c|c|c|c|c|c|c|c|c|c|c|c|c|c|}
\hline \multirow{2}{*}{ Assignments } & \multicolumn{15}{|c|}{ The compounds } \\
\hline & (I) & (Ia) & (Ib) & (Ic) & (Id) & (II) & (IIa) & (IIb) & (IIc) & (IId) & (III) & (IIIa) & (IIIb) & (IIIc) & (IIId) \\
\hline$v(\mathrm{OH})$ & ---- & 3458 & 3447 & 3460 & ---- & ---- & 3407 & 3435 & 3429 & 3429 & ---- & 3466 & 3396 & 3447 & 3392 \\
\hline$v\left(\mathrm{~N}^{4} \mathrm{H}\right)$ & 3306 & 3234 & 3230 & 3211 & 3300 & 3310 & 3237 & 3238 & 3305 & 3305 & 3310 & 3237 & 3238 & 3305 & 3305 \\
\hline$v\left(\mathrm{~N}^{2} \mathrm{H}\right)$ & 3196 & 3181 & 3175 & 3174 & 3198 & 3196 & 3179 & 3180 & 3194 & 3197 & 3196 & 3220 & 3202 & 3200 & 3198 \\
\hline$v(\mathrm{NH})$ & 3092 & 3111 & 3109 & 3100 & 3109 & 3111 & 3109 & 3111 & 3105 & 3111 & 3107 & 3115 & 3115 & 3109 & 3115 \\
\hline CH-arom. & 3064 & 3055 & 3030 & 3046 & 3000 & 3005 & 3034 & 3053 & 3005 & 3007 & 3005 & 3032 & 3039 & 3001 & 3007 \\
\hline CH-aliph. & 2940 & 2932 & 2941 & 2940 & 2940 & 2940 & 2980 & 2934 & 2938 & 2940 & 2940 & 2943 & 2938 & 2938 & 2940 \\
\hline$v(\mathrm{C}=\mathrm{O}) / v(\mathrm{NCO})$ & 1651 & 1595 & 1601 & 1593 & 1595 & 1657 & 1595 & 1599 & 1591 & 1599 & 1670 & 1595 & 1597 & 1595 & 1599 \\
\hline $\begin{array}{c}\text { Thioamide I } \\
{[\beta(\mathrm{NH}) / v(\mathrm{CN})]}\end{array}$ & 1402 & 1422 & 1443 & 1425 & 1435 & 1400 & 1420 & 1431 & 1416 & 1440 & 1400 & 1418 & 1450 & 1418 & 1445 \\
\hline $\begin{array}{c}\text { Thioamide II } \\
{[v(\mathrm{CN}) / \beta(\mathrm{NH})]}\end{array}$ & 1342 & 1398 & 1375 & 1362 & 1398 & 1341 & 1400 & 1400 & 1400 & 1400 & 1341 & 1368 & 1379 & 1377 & 1400 \\
\hline$\delta(\mathrm{OH})$ & ---- & 1307 & 1306 & 1308 & 1308 & ---- & 1306 & 1310 & 1310 & 1308 & ---- & 1307 & 1319 & 1310 & 1308 \\
\hline$v(\mathrm{C}-\mathrm{O})$ & ---- & 1292 & 1287 & 1287 & 1246 & ---- & 1290 & 1219 & 1273 & 1246 & ---- & 1245 & 1232 & 1246 & 1246 \\
\hline$v(\mathrm{~N}-\mathrm{N})$ & 902 & 934 & 941 & 924 & 924 & 902 & 935 & 945 & 924 & 925 & 923 & 975 & 960 & 966 & 964 \\
\hline$v(\mathrm{C}=\mathrm{S}) / v(\mathrm{C}-\mathrm{S})$ & 831 & 755 & 756 & 777 & 775 & 814 & 743 & 772 & 777 & 777 & 827 & 755 & 775 & 777 & 773 \\
\hline$v(\mathrm{M}-\mathrm{O})$ & ----- & 505 & 500 & 495 & 490 & ----- & 493 & 501 & 490 & 490 & ----- & 500 & 490 & 492 & 495 \\
\hline$v(\mathrm{M}-\mathrm{N})$ & ----- & 415 & 420 & 415 & 417 & ----- & 421 & 428 & 418 & 421 & ----- & 415 & 425 & 421 & 415 \\
\hline
\end{tabular}




\subsection{Thermal Investigation}

Thermogravimetric analysis (TGA and DTG) were carried out in dynamic nitrogen atmosphere $(30 \mathrm{ml} / \mathrm{min})$ with a heating rate of $10^{\circ} \mathrm{C} /$ min using a SchimadzuTGA-50H thermal analyzer (Figures S10-S12).

\subsection{Antibacterial Investigation}

Bacterial cultures and growth conditions: Gram negative Escherichia coli, Pseudomonas aeruginosa species and gram-positive Bacillus cereus, Staphylococcus aureus species and fungal Aspergillus fumingatus, Candidaalbicans were used as test microorganisms. The surface of the medium was inoculated and covered with the tested organisms. The agar surface was allowed to dry from 3 to 5 minutes before applying disks. The disks were dipped into a beaker of the chemicals using sterile forceps and placed them in the previous medium. Cultures plates of bacteria were incubated for grown at $37^{\circ} \mathrm{C}$ for 48 hours. Chloramphenicol was used as a standard antibacterial agent and Terbinafin was used as a standard antifungal agent.

\section{Results and Discussion}

\subsection{Infrared Spectra of $\mathrm{H}_{4} \mathrm{OxTSC}$ (I) and Its Metal Complexes}

The IR spectrum of compound I shows bands at 3306, 3196, and $3092 \mathrm{~cm}^{-1}$ for the free-NH groups present in the ligand. The bands occurring at 1651, 1402, 1342, 902 and $831 \mathrm{~cm}^{-1}$ are assigned to $v(\mathrm{C}=\mathrm{O})$, thioamide I $[\beta(\mathrm{NH})+v(\mathrm{CN})]$, thioamide II $[v(\mathrm{CN})+\beta(\mathrm{NH})], v(\mathrm{~N}-\mathrm{N})$ and $v(\mathrm{C}=\mathrm{S})$, respectively [22]-[27]. The assignments of the infrared bands, Table 1, were performed by comparing the spectra of the complexes with the free ligands. The bands due to $v(\mathrm{C}=\mathrm{S})$ and $v(\mathrm{C}=\mathrm{N})$ groups appeared at 802 and $1533 \mathrm{~cm}^{-1}$. On complexation, the bands of the thiosemicarbazide moiety respect to $v(\mathrm{C}=\mathrm{S})$ and $v(\mathrm{C}=\mathrm{N})$ are shifted towards higher wave numbers and notice that the very strong peak of $v(\mathrm{C}=\mathrm{S})$ may be disappeared or decreasing in its intensity. The bands due to $v(\mathrm{C}=\mathrm{S})$, $v(\mathrm{~N}-\mathrm{N})$ and $v(\mathrm{C}=\mathrm{N})$ groups appeared at 835,1101 and $1602 \mathrm{~cm}^{-1}$ (Figure 1).

The IR spectra of Copper complex Ia compared with ligand $\mathrm{H}_{4} \mathrm{OxTS}$, indicates that bands due to $v(\mathrm{NH})$, $v(\mathrm{C}=\mathrm{O})$ and $v(\mathrm{C}=\mathrm{S})$ are absent, but new bands appear at ca. 1651 and $831 \mathrm{~cm}^{-1}$ due to $v(\mathrm{~N}=\mathrm{C})$ and $v(\mathrm{C}-\mathrm{S})$, respectively, suggesting removal of both the hydrazinic protons via enolisation and thioenolisation and bonding of the resulting enolic oxygen and thiolato sulfur takes place with $\mathrm{Co}(\mathrm{II}), \mathrm{Cu}(\mathrm{II}), \mathrm{Zn}(\mathrm{II})$ and $\mathrm{Sn}(\mathrm{II})$. Furthermore, the ligand bands due to thioamide I, thioamide II and $v(\mathrm{~N}-\mathrm{N})$ undergo a positive shift of in the range (20 - 41 $\left.\mathrm{cm}^{-1}\right),\left(20-56 \mathrm{~cm}^{-1}\right)$ and $\left(22-39 \mathrm{~cm}^{-1}\right)$ respectively. Some new appear bands in the range $\left(755-777 \mathrm{~cm}^{-1}\right)$ assigned to groups (C-S) vibrations. This is also confirmed by the appearance of bands in the range of $395-417$ $\mathrm{cm}^{-1}$, this has been assigned to the $v(\mathrm{M}-\mathrm{N})$ [28], and the appearance of bands in the range of $490-505 \mathrm{~cm}^{-1}$, this has been assigned to the $v(\mathrm{M}-\mathrm{O})$. A strong band found at $902 \mathrm{~cm}^{-1}$ is due to the $v(\mathrm{~N}-\mathrm{N})$ group of the 1,1oxalylbis(4-phenyl-thiosemicarbazide. Thus the ligand behaves as tridentate chelating agent coordinating through azomethine nitrogen, thiolate sulphur andenolic oxygen (Figure 2, Figure 3).

\subsection{Raman Spectra}

The Raman spectrum shows bands at $3201 \mathrm{~cm}^{-1}$ for the NH groups present in $\mathrm{H}_{4} \mathrm{MaTS}$ ligand. The bands occurring at $1635,1405,1355,1088$ and $824 \mathrm{~cm}^{-1}$ are assigned to $v(\mathrm{C}=\mathrm{O})$, thioamide $\mathrm{I}[\beta(\mathrm{NH})+v(\mathrm{CN})]$, thioamide II $[v(\mathrm{CN})+\beta(\mathrm{NH})], v(\mathrm{~N}-\mathrm{N})$ and $v(\mathrm{C}=\mathrm{S})$, respectively [29]-[32] (Figure 4). An exhaustive comparison of the Raman spectra of the ligand and complexes gave information about the mode of bonding of the ligand in metal

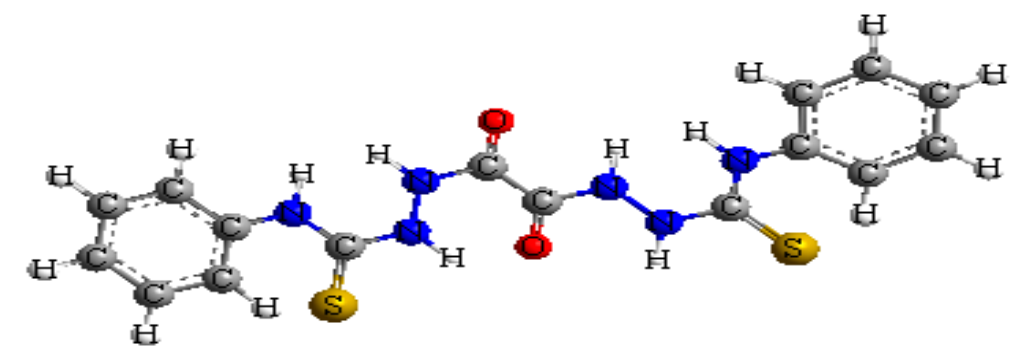

Figure 1. 1,1-Oxalyl-bis(4-phenylthiosemicarbazide) $\mathrm{H}_{4} \mathrm{OxTSC}$ (I). 


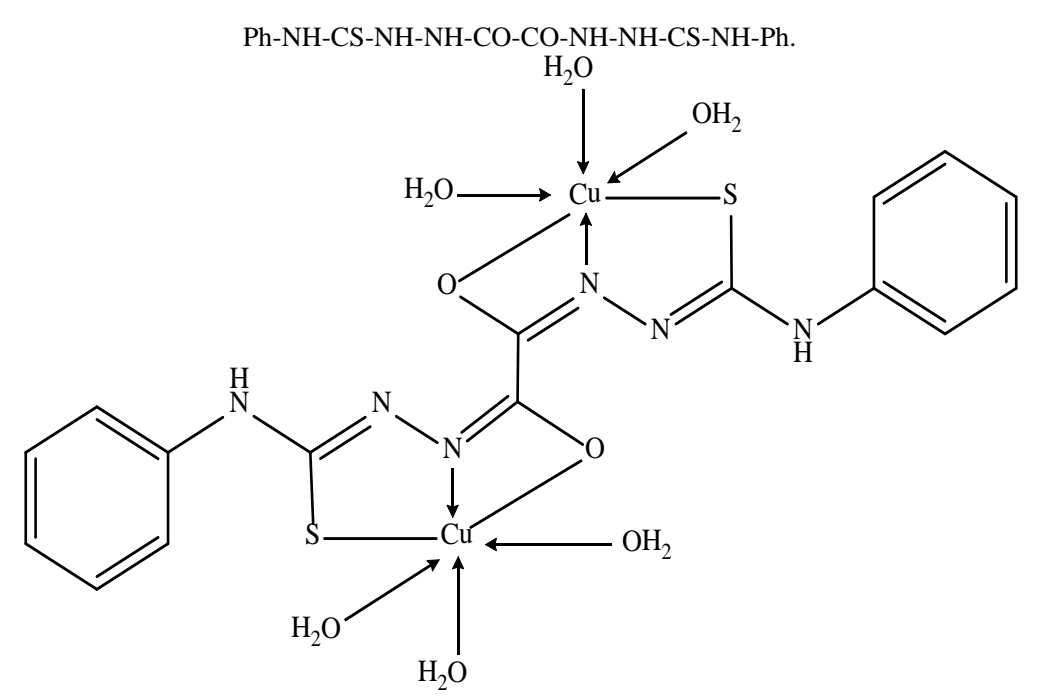

Figure 2. 1,1-Oxalaylbis(4-phenylthiosemicarbazide) bis-copper trihydrate (Ia).

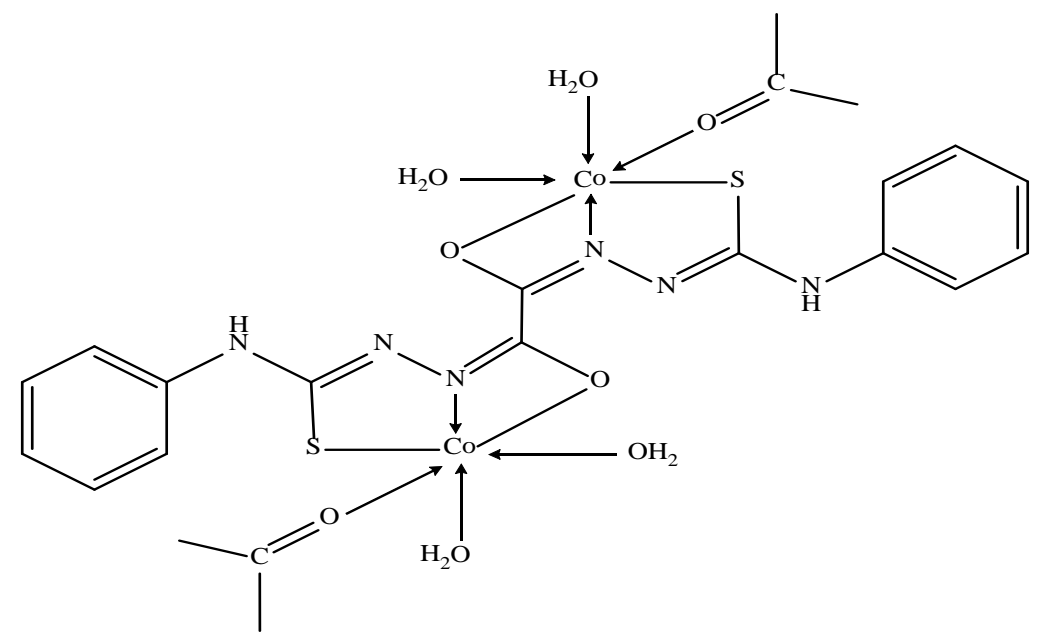

Figure 3. 1,1-Oxalaylbis-4-phenylthiosemicarbazide distorted octahedral cobalt monoacetonedihydrate (Ib).

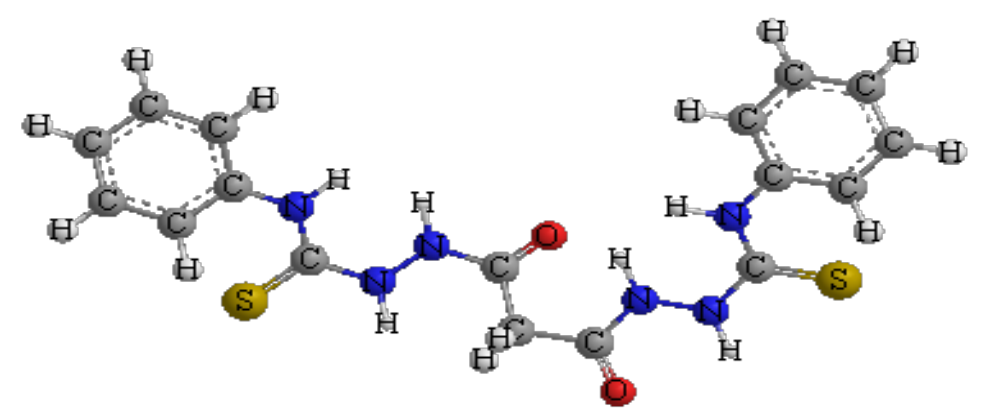

Figure 4. 1,1-Malonyl-bis(4-phenylthiosemicarbazide) $\mathrm{H}_{4} \mathrm{MaTSC}$ (II). Ph-NH$\mathrm{CS}-\mathrm{NH}-\mathrm{NH}-\mathrm{CO}-\mathrm{CH}_{2}-\mathrm{CO}-\mathrm{NH}-\mathrm{NH}-\mathrm{CS}-\mathrm{NH}-\mathrm{Ph}$.

complexes. The Raman spectrum of complexes $\left.\left[\mathrm{Zn}_{2}(\mathrm{MaTS})\left(\mathrm{H}_{2} \mathrm{O}\right)_{6}\right]\right)$ when compared with $\left[\mathrm{H}_{4} \mathrm{MaTS}\right]$, indicates that bands due to $v(\mathrm{NH}), v(\mathrm{C}=\mathrm{O})$ and $v(\mathrm{C}=\mathrm{S})$ are absent, but new bands appear at ca. 1593 and $779 \mathrm{~cm}^{-1}$ due to $v(\mathrm{~N}=\mathrm{C})$ and $v(\mathrm{C}-\mathrm{S})$, respectively, suggesting removal of both the hydrazinic protons via enolisation and thi- 
oenolisation and bonding of the resulting enolic oxygen and thiolato sulfur takes place with $\mathrm{Zn}(\mathrm{II})$. Furthermore, the ligand bands due to thioamide I, thioamide II and $v(\mathrm{~N}-\mathrm{N})$ undergo a positive shift of $\left(39 \mathrm{~cm}^{-1}\right),\left(40 \mathrm{~cm}^{-1}\right)$ and $\left(2 \mathrm{~cm}^{-1}\right)$ respectively. Ramanbands of complexes are appear of bands at $\left(779 \mathrm{~cm}^{-1}\right)$ assigned to groups (C-S) vibrations. It indicates that thione sulphur and also the enolic oxygen coordinates to the metal ion [33]-[35]. Thus, it may be concluded that the ligand behaves as hexadentate chelating agent coordinating through azomethine nitrogen and thiolate sulphur. The Raman spectrum of [ $\mathrm{H}_{4} \mathrm{SuTS}$ ] shows bands at 3201, 3095 and 3063 $\mathrm{cm}^{-1}$ for the two-NH groups present in the ligand. The bands occurring at 1650, 1405, 1355, 900 and $824 \mathrm{~cm}^{-1}$ are assigned to $v(\mathrm{C}=\mathrm{O})$, thioamide I $[\beta(\mathrm{NH})+v(\mathrm{CN})]$, thioamide II $[v(\mathrm{CN})+\beta(\mathrm{NH})], v(\mathrm{~N}-\mathrm{N})$ and $v(\mathrm{C}=\mathrm{S})$, respectively [33]-[35]. Raman spectral data of all the ligands and the metal complexes are summarized in Table 2.

\subsection{Electronic Spectra}

The electronic spectrum of $\left[\mathrm{Cu}_{2}(\mathrm{OxTS})\left(\mathrm{H}_{2} \mathrm{O}\right)_{6}\right] \cdot 3 \mathrm{H}_{2} \mathrm{O}$, Ia, has bands characteristic for an octahedral geometry [35]. The spectrum shows (Table 3) two bands at 20,600 and 31,950 $\mathrm{cm}^{-1}$ assigned to the ${ }^{4} \mathrm{~T}_{1} \mathrm{~g} \rightarrow{ }^{4} \mathrm{~A}_{2} \mathrm{~g}\left(v_{2}\right)$ and ${ }^{4} \mathrm{~T}_{1} \mathrm{~g} \rightarrow{ }^{4} \mathrm{~T}_{1} \mathrm{~g}(\mathrm{P})\left(v_{3}\right)$ transitions, respectively, in an octahedral structure. These bands were used to calculate the third spin-allowed band, ${ }^{4} \mathrm{~T}_{1} \mathrm{~g} \rightarrow{ }^{4} \mathrm{~T}_{1} \mathrm{~g}$ [20]. The other ligand field parameters, B, $\beta$ and the $v_{2} / v_{1}$ values were calculated to be $1060 \mathrm{~cm}^{-1}, 1.2$ and 2.2, respectively, and are in good agreement with those reported for octahedral $\mathrm{Co}(\mathrm{II})$ complexes. The electronic spectrum of $\left[\mathrm{Co}(\mathrm{OxTS})\left(\mathrm{H}_{2} \mathrm{O}\right)_{6}\right] \cdot 6 \mathrm{H}_{2} \mathrm{O}$, Ib, shows shoulder bands at 32,260 and 20,600 $\mathrm{cm}^{-1}$. The observed bands are due to ${ }^{2} \mathrm{~B}_{1} \mathrm{~g} \rightarrow{ }^{2} \mathrm{Eg}$ and ${ }^{2} \mathrm{~B}_{1} \mathrm{~g} \rightarrow{ }^{2} \mathrm{~A}_{1} \mathrm{~g}$ transitions, on the basis of octahedral geometry is suggested [35].

\subsection{Magnetic Susceptibility}

The observed values of magnetic moment for complexes are generally diagnostic of the coordination geometry about the metal ion. $\mathrm{Co}(\mathrm{II})$ has the electronic configuration $3 \mathrm{~d}^{*}$ and should exhibit a magnetic moment higher than that expected for two unpaired electrons in octahedral (1.5 - $3.3 \mathrm{BM})$. The magnetic moment observed for the Co(II) complexes lies in the value of $3.2 \mathrm{BM}$ which is consistent with the octahedral stereochemistry of the complexes. Room-temperature magnetic moment of the $\mathrm{Cu}(\mathrm{II})$ complexes lies in the range of $1.5 \mathrm{BM}$, corresponding to one unpaired electron.

\section{5. ${ }^{1} \mathrm{H}-\mathrm{NMR}$ Spectra}

The ${ }^{1} \mathrm{H}$-NMR spectra of compounds Ic and IIc on comparing with that of the ligands indicates that the ligands acts as a hex dentate through the nitrogen atom of $\mathrm{C}=\mathrm{N}$ oxygen atom of $\mathrm{C}=\mathrm{O}$ and sulfur atom of $\mathrm{C}=\mathrm{S}$. ${ }^{1} \mathrm{H}-\mathrm{NMR}$ spectrum of zinc (II) complex is in agreement with the suggested coordination through the $\mathrm{C}=\mathrm{N}$ and $\mathrm{C}=\mathrm{S}$ groups by the presence of the signals of (two from $2 \mathrm{NH}$ amine groups and two protons from $2 \mathrm{NH}$ amide groups).

Table 2. Significant Raman spectra bands $\left(\mathrm{cm}^{-1}\right)$ of 1,1-oxalyl, malonyl, succinyl-bis(4-phenylthiosemicarbazide) and its metal complexes.

\begin{tabular}{ccccccccc}
\hline \multirow{2}{*}{ Assignments } & \multicolumn{7}{c}{ The compounds } \\
\cline { 2 - 8 } & $(\mathbf{I})$ & $\mathbf{( I c )}$ & $\mathbf{( I d )}$ & $\mathbf{( I I )}$ & $\mathbf{( I I c )}$ & $\mathbf{( I I I )}$ & $\mathbf{( I I I c )}$ & (IIId) \\
\hline$v\left(\mathrm{~N}^{4} \mathrm{H}\right)$ & 3307 & ---- & ---- & 3201 & 3209 & 3201 & 3260 & 3300 \\
$v\left(\mathrm{~N}^{2} \mathrm{H}\right)$ & 3199 & 3205 & 3205 & 3063 & 3062 & 3095 & 3135 & 3100 \\
$\mathrm{CH}-$-arom. & 3063 & 3062 & 3063 & 2934 & 2933 & 3063 & 3064 & 3063 \\
$\mathrm{CH}-$-aliph. & 2935 & 2931 & 2925 & 1635 & 1593 & 3005 & 3004 & 3005 \\
$v(\mathrm{C}=\mathrm{O})$ & 1720 & ---- & ---- & 1405 & 1444 & 2934 & 2931 & 2925 \\
$v(\mathrm{C}=\mathrm{N})$ & 1596 & 1594 & 1595 & 1355 & 1395 & 1650 & 1596 & 1593 \\
$v(\mathrm{~N}-\mathrm{N})$ & 1090 & 1091 & 1125 & ---- & 1315 & 1405 & 1439 & 1450 \\
$v(\mathrm{C}=\mathrm{S})$ & 781 & 779 & 780 & 1088 & 1090 & 1355 & 1395 & 1390 \\
$v(\mathrm{M}-\mathrm{N})$ & ----- & 395 & 416 & 824 & 779 & ---- & 1319 & 1294 \\
\hline
\end{tabular}


Table 3. The electronic spectral data of oxalyl, malonyl and succinyl-bis(4-phenylthiosemicarbazide) and its metal complexes.

\begin{tabular}{|c|c|c|c|c|c|}
\hline \multirow{3}{*}{$\begin{array}{c}\text { Compounds } \\
\text { (I) }\end{array}$} & \multicolumn{5}{|c|}{$\lambda_{\max } \mathrm{nm}\left(\mathrm{cm}^{-1}\right)$} \\
\hline & \multirow{2}{*}{$\begin{array}{c}\boldsymbol{\pi}-\boldsymbol{\pi}^{*}, \mathrm{C}=\mathrm{S} \\
256,(39060)\end{array}$} & \multirow{2}{*}{$\begin{array}{c}\mathbf{n}-\boldsymbol{\pi}^{*}, \mathbf{C}=\mathbf{S} \\
314,(31850)\end{array}$} & \multicolumn{3}{|c|}{ d-d transition } \\
\hline & & & ----- & ----- & ----- \\
\hline (Ia) & $260,(38460)$ & 313, (31950) & 494, (20240) & 559, (17889) & 578, (17300) \\
\hline (Ib) & 268, (37300) & 310, (32260) & 486, (20600) & 540, (18520) & ------ \\
\hline (Ic) & $265,(37740)$ & $317,(31550)$ & ------ & ------ & ------ \\
\hline (Id) & 266, (37600) & 324, (30860) & ------ & ------ & ------ \\
\hline (II) & 287, (34840) & 344, (29070) & ------ & ------ & ----- \\
\hline (IIa) & 288, (34720) & 342, (29240) & 462, (21650) & 485, (20620) & 522, (19160) \\
\hline (IIb) & 308, (32470) & 358, (27930) & 466, (21460) & 493, (20280) & 524, (19080) \\
\hline (IIc) & 284, (35210) & 344, (29070) & ------ & ------ & ----- \\
\hline (IId) & 288, (34720) & 330, (30300) & ------ & ------ & ----- \\
\hline (III) & 264, (37880) & $328,(30490)$ & ------ & ----- & ---- \\
\hline (IIIa) & 296, (33780) & 356, (28090) & 540, (18520) & $600,(16670)$ & 622, (16080) \\
\hline (IIIb) & 256, (39060) & $320,(31250)$ & 543, (18420) & 610, (16390) & ----- \\
\hline (IIIc) & $280,(35710)$ & 332, (30120) & ----- & ---- & ----- \\
\hline (IIId) & $260,(38460)$ & 304, (32890) & ---- & ---- & ---- \\
\hline
\end{tabular}

( $\left.\mathrm{H}_{4} \mathrm{OxTS}\right){ }^{1} \mathrm{H}-\mathrm{NMR} \delta$ (ppm): 9.75(N5, 17H amide group), 1.95(N6, 18H amine group), 3.6(CN9, 21H aromatic), 6.6 - 7.5(CH-aromatic).

$\left[\mathrm{Zn}_{2}(\mathrm{OxTS})(\mathrm{ac})_{2}\right] \cdot 2 \mathrm{H}_{2} \mathrm{O}^{1} \mathrm{H}-\mathrm{NMR} \delta(\mathrm{ppm}): 1.19\left(\mathrm{CH}_{3}\right.$ acetone), 2.7( $\left.\mathrm{H}_{2} \mathrm{O}\right)(\mathrm{NH}$ amide groups disappeared), ( $\mathrm{NH}$ amine groups disappeared), 3.5(9,21CNH aromatic), 6.6-7.5(CH-aromatic shifted).

( $\left.\mathrm{H}_{4} \mathrm{SuTS}\right)^{1} \mathrm{H}-\mathrm{NMR} \delta$ (ppm): 9.7(7,19NH amide group), 1.95(8, 20NH amine group),4(11, 23CNH aromatic), 2.5(3, 4 $\left.4 \mathrm{CH}_{2}\right) 6.6$ - 7.75(CH-aromatic).

$\left[\mathrm{Zn}_{2}(\mathrm{SuTS})(\mathrm{ac})_{2}\right] 2\left(\mathrm{H}_{2} \mathrm{O}\right)^{1} \mathrm{H}-\mathrm{NMR} \delta(\mathrm{ppm}): 1.1\left(\mathrm{H}_{2} \mathrm{O}\right), 1.2\left(\mathrm{CH}_{3}\right.$ acetone) (NH amide groups disappeared), ( $\mathrm{NH}$ amine groups disappeared), 2.5( $\left(\mathrm{CH}_{2}\right), 4(\mathrm{CNH}$ aromatic), 6.6 - 7.75(CH-aromatic shifted).

\subsection{Mass Spectrum}

The electronic impact mass spectrum of the ligand I shows a molecular ion $(\mathrm{M}+)$ peak at $\mathrm{m} / \mathrm{z}=243$ amu corresponding to species $\mathrm{C}_{9} \mathrm{H}_{7} \mathrm{~N}_{3} \mathrm{OS}$, which confirms the proposed formula. It also shows series of peaks at 70, 88, 111 , 127 and 170 amu corresponding to various fragments. The intensities of these peaks give the idea of the stabilities of the fragments. The electronic impact mass spectrum of the Ia complex 1,1-oxalayl-bis (phenylthiosemicarbazide) cobalt monoacetone dehydrate shows a molecular ion $(\mathrm{M}+$ ) peak at $\mathrm{m} / \mathrm{z}=758$ amu corresponding to species $\left[\mathrm{C}_{22} \mathrm{H}_{30} \mathrm{Co}_{2} \mathrm{~N}_{6} \mathrm{O}_{8} \mathrm{~S}_{2}\right]$, which confirms the proposed formula. It also shows series of peaks at 39, 75, 90 , 111, 127, 138, 169, 184, 201, 226, 243, 271 and 336 amu corresponding to various fragments.

\section{Thermogravimetric Analysis}

Thermogravimetric analysis curves (TGA and DTG) of I, Ia, Ib and Ic are discussed (Tables 4-6). Compound I was thermally decomposed in mainly decomposition steps within the temperature range $25^{\circ} \mathrm{C}-700^{\circ} \mathrm{C}$. The first step (obs. $=42.5 \%$, calc. $=42.4 \%$ ) at $25^{\circ} \mathrm{C}-237^{\circ} \mathrm{C}$, may be attributed to the liberation of the $2\left(\mathrm{~N}_{2} \mathrm{H}_{2}\right), 2(\mathrm{HCNS})$ and $1 / 2 \mathrm{O}_{2}$ fragments. The second step at $237^{\circ} \mathrm{C}-337^{\circ} \mathrm{C}$ (obs. $=30.2 \%$, calc. $=30.4 \%$ ), is accounted for the removal of $1 / 2 \mathrm{O}_{2}$ and $\mathrm{C}_{4} \mathrm{H}_{4}$.

The complex Ia was thermally decomposed in five successive decomposition steps within the temperature 
range $25^{\circ} \mathrm{C}-1000^{\circ} \mathrm{C}$. The first step (obs. $=6 \%$, calc. $=6.6 \%$ ) at $25^{\circ} \mathrm{C}-175^{\circ} \mathrm{C}$, may be attributed to the liberation of the 3 water molecules. The second step at $175^{\circ} \mathrm{C}-390^{\circ} \mathrm{C}$ (obs. $=29.2 \%$, calc. $=28.6 \%$ ), is accounted for the removal of 2 acetone, 4 water and $\mathrm{N}_{3} \mathrm{H}_{3}$ fragment. The decomposition third step at $390^{\circ} \mathrm{C}-707^{\circ} \mathrm{C}$ (obs. $=18.3 \%$, calc $=18.9 \%)$ is accounted for the removal of $\left(\mathrm{C}_{4} \mathrm{~N}_{3} \mathrm{~S}_{2}\right)$ fragment. The fourth step at $707^{\circ} \mathrm{C}-990^{\circ} \mathrm{C}$ (obs. $=$ $22.8 \%$, calc $=22.8 \%)$ is accounted for the removal of $\left(\mathrm{C}_{9} \mathrm{H}_{7}\right)$ fragment. The rest of the ligand molecule was removed and fifth the decomposition of the $\mathrm{Co}(\mathrm{II}) / \mathrm{L}$ complex molecule ended with a final $2 \mathrm{CoO}$ and residual carbon $3 / 2 \mathrm{C}_{2}$ fragment (obs. $=23.7 \%$, calc $=22.9 \%$ ).

The TG curve of $\mathbf{I b}$ complex indicates that the mass change begins at $25^{\circ} \mathrm{C}$ and continuous up to $1000^{\circ} \mathrm{C}$. The first and second mass loss corresponds to the liberation of the 12 water molecules and two (HCN) fragment (obs. $=34.4 \%$, calc $=33.9 \%)$ at $25^{\circ} \mathrm{C}-342^{\circ} \mathrm{C}$. The third step occurs in the range $342^{\circ} \mathrm{C}-475^{\circ} \mathrm{C}$ and corresponds to the loss of $\left(\mathrm{CN}_{4} \mathrm{~S}\right)$ (obs. $=12.8 \%$, calc $\left.=12.6 \%\right)$. The fourth and fifth decomposition step are final decomposition organic ligand to the $\mathrm{C}_{13} \mathrm{H}_{8}, 1 / 2 \mathrm{~S}_{2}, \mathrm{O}_{2}$ fragments and $\mathrm{Cu}_{2}$ metal residual atoms (obs. $=52.8 \%$, calc $=53.4 \%$ ).

Ic complex was thermally decomposed in mainly five decomposition steps within the temperature range $25^{\circ} \mathrm{C}$ $-700^{\circ} \mathrm{C}$. The first decomposition step (obs. $=20.64 \%$, calc $=20.64 \%$ ) at $25^{\circ} \mathrm{C}-245^{\circ} \mathrm{C}$, may be attributed to the liberation of two water and two acetone molecules. The second step at $245^{\circ} \mathrm{C}-386^{\circ} \mathrm{C}$ (obs. $=23.4 \%$, calc $=$ $23.6 \%$ ) is accounted for the removal of the $2(\mathrm{HCN}), 2 \mathrm{~N}_{2}$ and $\mathrm{S}_{2}$ fragments. The third step found within the temperature $386^{\circ} \mathrm{C}-700^{\circ} \mathrm{C}$ (obs. $=19.7 \%$, calc $=19.96 \%$ ). The rest of the ligand molecule was removed and fourth the decomposition of theligand molecule ended with a final residue of $\left(\mathrm{C}_{8} \mathrm{H}_{4}\right),(\mathrm{ZnO})$ and zinc metal (obs. = $36.3 \%$, calc $=35.7 \%$ ).

Ligand II was thermally decomposed in mainly decomposition steps within the temperature range successive

Table 4. The thermal data of 1,1-oxalylbis(4-phenylthiosemicarbazide) and its metal complexes.

\begin{tabular}{|c|c|c|c|c|c|c|}
\hline \multirow{2}{*}{ Compound } & \multirow{2}{*}{ Steps } & \multirow{2}{*}{$\begin{array}{l}\text { Temperature } \\
\text { range }\left({ }^{\circ} \mathrm{C}\right)\end{array}$} & \multicolumn{2}{|c|}{ TG weight loss (\%) } & \multirow{2}{*}{ Assignment } & \multirow{2}{*}{$\mathrm{T}_{\max }$} \\
\hline & & & Calc. \% & Found \% & & \\
\hline \multirow{3}{*}{ (I) } & 1 & $25-237$ & 42.40 & 42.50 & $2\left(\mathrm{~N}_{2} \mathrm{H}_{2}\right), 2(\mathrm{HCNS})$ and $1 / 2 \mathrm{O}_{2}$ fragments & \multirow{3}{*}{$\begin{array}{l}205 \\
280 \\
565\end{array}$} \\
\hline & 2 & $237-337$ & 30.40 & 30.20 & $1 / 2 \mathrm{O}_{2}$ and $\mathrm{C}_{4} \mathrm{H}_{4}$ & \\
\hline & 3 & More than 337 & 27.10 & 27.30 & $\mathrm{C}_{10} \mathrm{H}_{4}$ & \\
\hline \multirow{5}{*}{ (Ia) } & 1 & $25-175$ & 6.60 & 6.00 & 3 water & \multirow{4}{*}{$\begin{array}{l}166 \\
278 \\
777 \\
869\end{array}$} \\
\hline & 2 & $175-390$ & 28.50 & 29.20 & 2 acetone, 4 water and $\mathrm{N}_{3} \mathrm{H}_{3}$ & \\
\hline & 3 & $390-707$ & 18.90 & 18.30 & $\left(\mathrm{C}_{4} \mathrm{~N}_{3} \mathrm{~S}_{2}\right)$ & \\
\hline & 4 & $707-990$ & 22.80 & 22.80 & $\left(\mathrm{C}_{9} \mathrm{H}_{8}\right)$ & \\
\hline & 5 & More than 990 & 22.90 & 23.70 & $2 \mathrm{CoO}$ and residual carbon $3 / 2 \mathrm{C}_{2}$ & \multirow{4}{*}{$\begin{array}{c}187,271 \\
405,480 \\
840 \\
978\end{array}$} \\
\hline \multirow{3}{*}{ (Ib) } & 1,2 & $25-342$ & 33.90 & 34.40 & 12water and 2(HCN) & \\
\hline & 3 & $342-475$ & 12.60 & 12.80 & $\left(\mathrm{CN}_{4} \mathrm{~S}\right)$ & \\
\hline & 4,5 & More than 475 & 53.40 & 52.80 & $\begin{array}{c}\left(\mathrm{C}_{13} \mathrm{H}_{10}\right),(\mathrm{S}),\left(\mathrm{O}_{2}\right) \text { molecules and } 2 \mathrm{Cu}(\mathrm{II}) \\
\text { metal }\end{array}$ & \\
\hline \multirow{4}{*}{ (Ic) } & 1 & $25-245$ & 20.64 & 20.64 & two water and two acetone molecules & \multirow{4}{*}{$\begin{array}{l}228 \\
319 \\
493 \\
649\end{array}$} \\
\hline & 2 & $245-386$ & 23.60 & 23.40 & $2(\mathrm{HCN}), 2 \mathrm{~N}_{2}$ and $\mathrm{S}_{2}$ & \\
\hline & 3 & $386-700$ & 19.96 & 19.70 & $\mathrm{C}_{6} \mathrm{H}_{4}$ & \\
\hline & 4 & More than 700 & 35.70 & 36.30 & $\left(\mathrm{C}_{8} \mathrm{H}_{4}\right),(\mathrm{ZnO})$ and zinc metal residue & \\
\hline \multirow{4}{*}{ (Id) } & 1 & $25-226$ & 12.40 & 12.60 & two water and 2(HCN) molecules & \multirow{4}{*}{$\begin{array}{l}224 \\
301 \\
530\end{array}$} \\
\hline & 2 & $226-322$ & 16.50 & 16.20 & $\mathrm{~S}_{2}$ and $2 \mathrm{~N}_{2}$ & \\
\hline & 3 & $322-560$ & 16.90 & 17.20 & $\mathrm{C}_{4} \mathrm{H}_{4}$ & \\
\hline & 4 & More than 560 & 54.10 & 54.00 & $\mathrm{C}_{10} \mathrm{H}_{4},(\mathrm{SnO})$ and $\mathrm{Sn}$ metal residue & \\
\hline
\end{tabular}


Table 5. The thermal data of 1,1-malonayl-bis(4-phenyl thiosemicarbazide) and its metal complexes.

\begin{tabular}{|c|c|c|c|c|c|c|}
\hline \multirow{2}{*}{ Compound } & \multirow{2}{*}{ Steps } & \multirow{2}{*}{$\begin{array}{l}\text { Temperature } \\
\text { ring }\left({ }^{\circ} \mathrm{C}\right)\end{array}$} & \multicolumn{2}{|c|}{ TG weight loss (\%) } & \multirow{2}{*}{ Assignments } & \multirow{2}{*}{$\mathrm{T}_{\max } /{ }^{\circ} \mathrm{C}$} \\
\hline & & & Calc. & Found & & \\
\hline \multirow{4}{*}{ (II) } & 1 & $25-245$ & 39.00 & 39.10 & $2(\mathrm{HNCO}), 2 \mathrm{H}_{2} \mathrm{~S}$ and $2(\mathrm{NH})$ fragments & \multirow{4}{*}{$\begin{array}{l}212 \\
278 \\
524\end{array}$} \\
\hline & 2 & $245-345$ & 32.50 & 32.80 & 2(HCN), $\left(\mathrm{C}_{2} \mathrm{H}_{2}\right)$ & \\
\hline & 3 & More than 345 & 26.80 & 27.50 & $\left(\mathrm{C}_{17} \mathrm{H}_{2}\right)$ residual & \\
\hline & 1 & $25-188$ & 4.94 & 5.20 & 2 water & \\
\hline \multirow{3}{*}{ (IIa) } & 2 & $188-448$ & 33.50 & 33.10 & $\begin{array}{c}6 \text { water molecules, } 2 \mathrm{~N}_{2}, 2(\mathrm{HCN}) \text {, and } \mathrm{C}_{2} \mathrm{H}_{2} \\
\text { fragments }\end{array}$ & \multirow{3}{*}{$\begin{array}{l}242 \\
477 \\
854 \\
959\end{array}$} \\
\hline & 3 & $448-760$ & 22.90 & 23.40 & $\mathrm{~S}_{2}$ and $\mathrm{O}_{2}$ molecules & \\
\hline & 4 & $760-885$ & 22.50 & 21.80 & $\mathrm{CH}_{4}$ and $\mathrm{C}_{12} \mathrm{H}_{4}$ fragments & \\
\hline \multirow{6}{*}{ (IIb) } & 5 & More than 885 & 16.50 & 17.30 & $\mathrm{Co}_{2}$ molecule is cobalt residue & \multirow{6}{*}{$\begin{array}{l}181 \\
277 \\
506 \\
680 \\
974\end{array}$} \\
\hline & 1,2 & $25-245$ & 15.40 & 16.40 & 6 water & \\
\hline & 3 & $245-475$ & 20.50 & 20.60 & $\mathrm{~N}_{2}, 2(\mathrm{HCN}), \mathrm{N}_{2} \mathrm{H}_{2}$, and $\mathrm{O}_{2}$ & \\
\hline & 4 & $475-765$ & 42.50 & 42.40 & $\mathrm{C}_{13} \mathrm{H}_{8}, \mathrm{~S}_{2}$ ) fragments & \\
\hline & 5 & More than 765 & 21.50 & 20.60 & $\mathrm{Cu}_{2}$ metal residual & \\
\hline & 1 & $25-224$ & 15.300 & 15.50 & 6 water molecules & \\
\hline \multirow{3}{*}{ (IIc) } & 2 & $224-338$ & 26.90 & 26.50 & $2 \mathrm{~N}_{2}, \mathrm{~S}_{2}, 1 / 2 \mathrm{O}_{2}$ and $2(\mathrm{HCN})$ fragment & \multirow{3}{*}{$\begin{array}{l}219 \\
309\end{array}$} \\
\hline & 3 & $338-643$ & 18.20 & 18.60 & $1 / 2 \mathrm{O}_{2}, \mathrm{CH}_{4}$ and $\mathrm{C}_{2} \mathrm{H}_{2}$ molecules & \\
\hline & 4 & More than 643 & 39.50 & 39.40 & residue metal of $\mathrm{Zn}_{2}$ and $\mathrm{C}_{12} \mathrm{H}_{4}$ fragment & \\
\hline \multirow{4}{*}{ (IId) } & 1,2 & $25-322$ & 25.20 & 24.70 & $8 \mathrm{H}_{2} \mathrm{O}$, HNCO and $\mathrm{HCN}$ molecules & \multirow{4}{*}{$\begin{array}{l}229 \\
301 \\
518\end{array}$} \\
\hline & 3 & $322-506$ & 8.80 & 9.30 & $1 / 2 \mathrm{~S}_{2}$ and $\mathrm{HNCO}$ & \\
\hline & 4 & $506-589$ & 9.10 & 9.56 & $\mathrm{NH}_{3}, \mathrm{~N}_{2}$ and $1 / 2 \mathrm{~S}_{2}$ molecules & \\
\hline & 5 & More than 589 & 56.80 & 56.44 & $\mathrm{C}_{14} \mathrm{H}_{6}$ and $\mathrm{Sn}_{2}$ the residual metal & \\
\hline
\end{tabular}

Table 6. The thermal data of 1,1-succinyl-bis(4-phenylthiosemi carbazide) and its metal complexes.

\begin{tabular}{|c|c|c|c|c|c|c|}
\hline \multirow{2}{*}{ Compound } & \multirow{2}{*}{ steps } & \multirow{2}{*}{$\begin{array}{l}\text { Temperature } \\
\text { range }\left({ }^{\circ} \mathrm{C}\right)\end{array}$} & \multicolumn{2}{|c|}{ TG weight loss (\%) } & \multirow{2}{*}{ Assignment } & \multirow{2}{*}{$\mathbf{T}_{\max }^{\circ} \mathrm{C}$} \\
\hline & & & Calc. & Found & & \\
\hline \multirow{3}{*}{ (III) } & 1 & $25-234$ & 35.80 & 36.00 & $2(\mathrm{HCN}), 2 \mathrm{~N}_{2}$ and $\mathrm{S}_{2}$ fragments & \multirow{3}{*}{$\begin{array}{l}211 \\
276 \\
503\end{array}$} \\
\hline & 2 & $234-334$ & 32.30 & 32.10 & $\mathrm{O}_{2}$ and $\mathrm{C}_{4} \mathrm{H}_{6}$ & \\
\hline & 3 & More than 334 & 31.70 & 31.90 & $\mathrm{C}_{12} \mathrm{H}_{10}$ & \\
\hline \multirow{4}{*}{ (IIIa) } & 1 & $25-332$ & 32.00 & 31.90 & 6 water and 2(HCN) and $\mathrm{N}_{2} \mathrm{H}_{2}$ & \multirow{4}{*}{$\begin{array}{l}246 \\
473 \\
704 \\
828\end{array}$} \\
\hline & 2 & $332-550$ & 16.80 & 16.90 & $\mathrm{~S}_{2}, \mathrm{O}_{2}$ and $\mathrm{C}_{2} \mathrm{H}_{2}$ & \\
\hline & 3 & $550-895$ & 24.80 & 24.60 & $\mathrm{C}_{8} \mathrm{H}_{6}$ & \\
\hline & 4 & More than 895 & 26.80 & 26.60 & $3 / 2 \mathrm{C}_{2}$ and $\mathrm{Co}_{2}$ metal & \\
\hline \multirow{4}{*}{ (IIIb) } & 1 & $25-465$ & 17.80 & 17.80 & 10water & \multirow{4}{*}{$\begin{array}{l}208 \\
540 \\
840 \\
977\end{array}$} \\
\hline & 2 & $465-700$ & 14.80 & 15.00 & 2(HCN), $2 \mathrm{~N}_{2}$ and $2\left(\mathrm{CH}_{2}\right)$ & \\
\hline & 3 & $700-910$ & 34.70 & 33.90 & $2\left(\mathrm{C}_{6} \mathrm{H}_{4}\right)$ and $2 \mathrm{~S}_{2}$ & \\
\hline & 4,5 & $910-1000$ & 32.60 & 33.27 & Carbon and 4(CuO) & \\
\hline \multirow{3}{*}{ (IIIc) } & 1 & $25-237$ & 19.90 & 20.00 & two water and two acetone molecules & \multirow{3}{*}{$\begin{array}{l}221 \\
348 \\
560\end{array}$} \\
\hline & 2 & $237-365$ & 25.38 & 25.30 & 2(HCN) 2(HNCO) $2 \mathrm{CH}$ and $\mathrm{N}_{2}$ fragment & \\
\hline & 3 & More than 365 & 54.66 & 54.70 & $\mathrm{~S}_{2},\left(\mathrm{C}_{6} \mathrm{H}_{4}\right)$ and $\mathrm{Zn}_{2}$ & \\
\hline \multirow{4}{*}{ (IIId) } & 1 & $25-239$ & 13.10 & 13.00 & 6 water molecules & \multirow{4}{*}{$\begin{array}{l}226 \\
302 \\
530 \\
572\end{array}$} \\
\hline & 2 & $239-321$ & 13.30 & 12.70 & $2 \mathrm{HCN}$ and $2 \mathrm{~N}_{2}$ & \\
\hline & 3,4 & $321-700$ & 20.20 & 20.80 & $\mathrm{~S}_{2}$ and $\mathrm{O}_{2}$ fragments & \\
\hline & 5 & More than 700 & 53.40 & 53.50 & $\begin{array}{l}\text { residue metal of } \mathrm{Sn}_{2} \text { and contaminated of } \\
\left(\mathrm{C}_{16} \mathrm{H}_{12}\right) \text { fragments }\end{array}$ & \\
\hline
\end{tabular}


decomposition steps at $25^{\circ} \mathrm{C}-700^{\circ} \mathrm{C}$. The first decomposition step (obs. $=39.14 \%$, calc. $=39 \%$ ) at $25^{\circ} \mathrm{C}-245^{\circ} \mathrm{C}$, may be attributed to the liberation of $2(\mathrm{HNCO}), 2 \mathrm{H}_{2} \mathrm{~S}$ and $2(\mathrm{NH})$ fragments. The second decomposition step at $245^{\circ} \mathrm{C}-345^{\circ} \mathrm{C}$ (obs. $=32.8 \%$, calc. $=32.5 \%$ ), is accounted for the removal of $2(\mathrm{HCN})$ and $\left(\mathrm{C}_{2} \mathrm{H}_{2}\right)$. The decomposition of the ligand molecule ended with a final $\left(\mathrm{C}_{17} \mathrm{H}_{2}\right)$ residue (obs. $=28 \%$, calc $=28.3 \%$ ).

The complex IIa was thermally decomposed in five steps within the temperature range $25^{\circ} \mathrm{C}-1000^{\circ} \mathrm{C}$. The first step (obs. $=5.2 \%$, calc. $=4.94 \%$ ) at $25^{\circ} \mathrm{C}-188^{\circ} \mathrm{C}$, may be attributed to the liberation of the two $\mathrm{H}_{2} \mathrm{O}$ molecules. The second step at $188^{\circ} \mathrm{C}-448^{\circ} \mathrm{C}$ (obs. $=33.1 \%$, calc. $=33.5 \%$ ), is accounted for the removal of $6 \mathrm{H}_{2} \mathrm{O}$, $2 \mathrm{~N}_{2}, 2\left(\mathrm{HCN}\right.$ ), and $\mathrm{C}_{2} \mathrm{H}_{2}$ fragments. The decomposition third step at $448^{\circ} \mathrm{C}-760^{\circ} \mathrm{C}$ (obs. $=23.4 \%$, calc $=22.9 \%$ ) is accounted for the removal of $\mathrm{S}_{2}$ and $\mathrm{O}_{2}$ molecules. The fourth step found at $760^{\circ} \mathrm{C}-885^{\circ} \mathrm{C}$ (obs. $=21.8 \%$, calc $=22.5 \%$ ) is accounted for the removal of $\mathrm{CH}_{4}$ and $\mathrm{C}_{12} \mathrm{H}_{4}$ fragments.

The TG curve of IIb complex indicates that the mass change begins at $25^{\circ} \mathrm{C}$ and continuous up to $1000^{\circ} \mathrm{C}$. The first and second mass loss corresponds to the liberation of the $6 \mathrm{H}_{2} \mathrm{O}$ molecules (obs. $=16.4 \%$, calc $=15.4 \%$ ) at $25^{\circ} \mathrm{C}-245^{\circ} \mathrm{C}$. The third step occurs in the range $245^{\circ} \mathrm{C}-475^{\circ} \mathrm{C}$ and corresponds to the loss of $\mathrm{N}_{2}, 2(\mathrm{HCN})$, $\mathrm{N}_{2} \mathrm{H}_{2}$, and $\mathrm{O}_{2}$ (obs. $=20.6 \%$, calc $=20.5 \%$ ). The fourth step at $475^{\circ} \mathrm{C}-765^{\circ} \mathrm{C}$ (obs. $=42.4 \%$, calc $=42.5 \%$ ) is accounted for the removal of $\left(\mathrm{C}_{13} \mathrm{H}_{8}, \mathrm{~S}_{2}\right)$ fragments. The fifth steps are final decomposition organic ligand to the $\mathrm{C}_{2}$ and $\mathrm{Cu}_{2}$ residual (obs. $=20.6 \%$, calc $=21.5 \%$ ).

The complex IIc was thermally decomposed in mainly four steps within the temperature range $25^{\circ} \mathrm{C}-700^{\circ} \mathrm{C}$. The first decomposition step (obs. $=15.5 \%$, calc $=15.3 \%$ ) at $25^{\circ} \mathrm{C}-224^{\circ} \mathrm{C}$, may be attributed to the liberation of $6 \mathrm{H}_{2} \mathrm{O}$. The second step at $224^{\circ} \mathrm{C}-338^{\circ} \mathrm{C}$ (obs. $=26.5 \%$, calc $=26.9 \%$ ) is accounted for the removal of $2 \mathrm{~N}_{2}, \mathrm{~S}_{2}$, $1 / 2 \mathrm{O}_{2}$ and $2(\mathrm{HCN})$ fragment. The decomposition third step found within the temperature $338^{\circ} \mathrm{C}-643^{\circ} \mathrm{C}$ (obs. $=$ $18.6 \%$, calc $=18.2 \%$ ) is accounted for the removal of $1 / 2 \mathrm{O}_{2}, \mathrm{CH}_{4}$ and $\mathrm{C}_{2} \mathrm{H}_{2}$ fragments. The rest of the ligand molecule was removed and fourth the decomposition of the ligand molecule ended with a final residue metal of $\mathrm{Zn}_{2}$ and $\mathrm{C}_{12} \mathrm{H}_{4}$ fragment (obs. $=39.4 \%$, calc $=39.5 \%$ ).

Ligand III was thermally decomposed in mainly decomposition steps within the temperature range successive decomposition steps within the temperature range $25^{\circ} \mathrm{C}-700^{\circ} \mathrm{C}$ (Figure 5). The first decomposition step (obs. = $36 \%$, calc. $=35.8 \%$ ) within the temperature range $25^{\circ} \mathrm{C}-234^{\circ} \mathrm{C}$, may be attributed to the liberation of the 2(HCN), $2 \mathrm{~N}_{2}$ and $\mathrm{S}_{2}$ fragments. The second decomposition steps found within the temperature range $234^{\circ} \mathrm{C}$ $334^{\circ} \mathrm{C}$ (obs. $=32.1 \%$, calc. $=32.3 \%$ ), which is reasonably accounted by the removal of $\mathrm{O}_{2}$ and $\mathrm{C}_{4} \mathrm{H}_{6}$. The decomposition of the ligand molecule ended with a final $\mathrm{C}_{12} \mathrm{H}_{10}$ residue (obs. $=31.86 \%$, calc $=31.7 \%$ ).

The complex IIIa was thermally decomposed in four successive decomposition steps within the temperature range $25^{\circ} \mathrm{C}-1000^{\circ} \mathrm{C}$. The first decomposition step (obs. $=31.9 \%$, calc. $=32 \%$ ) within the temperature range $25^{\circ} \mathrm{C}-332^{\circ} \mathrm{C}$, may be attributed to the liberation of the 6water molecules, 2(HCN) and $\mathrm{N}_{2} \mathrm{H}_{2}$ fragments. The second decomposition steps found within the temperature range $332^{\circ} \mathrm{C}-550^{\circ} \mathrm{C}$ (obs. $=16.9 \%$, calc. $=16.8 \%$ ), which is reasonably accounted by the removal $\mathrm{S}_{2}, \mathrm{O}_{2}$ and $\mathrm{C}_{2} \mathrm{H}_{2}$ fragments. The rest of the ligand molecule was removed and fourth the decomposition of the $\mathrm{Co}(\mathrm{II}) / \mathrm{L}$ complex molecule ended with a final $3 / 2 \mathrm{C}_{2}$ and $\mathrm{Co}_{2}$ metal is cobalt residue (obs. $=26.6 \%$, calc $=26.8 \%$ ).

The TG curve of complex IIIb indicates that the mass change begins at $25^{\circ} \mathrm{C}$ and continuous up to $1000^{\circ} \mathrm{C}$. The first mass loss corresponds to the liberation of the 12 water molecules (obs. $=17.8 \%$, calc $=17.8 \%$ ) within the temperature range $25^{\circ} \mathrm{C}-465^{\circ} \mathrm{C}$, (Figure 6). The second decomposition steps found within the temperature range $465^{\circ} \mathrm{C}-700^{\circ} \mathrm{C}$ (obs. $=15 \%$, calc. $=14.8 \%$ ), which is reasonably accounted by the removal of $2(\mathrm{HCN})$, $2 \mathrm{~N}_{2}$ and $2\left(\mathrm{CH}_{2}\right)$ fragments. The decomposition fourth and fifth decomposition step are final decomposition organic ligand to the found within the temperature $910^{\circ} \mathrm{C}$-more than $1000^{\circ} \mathrm{C}$ (obs. $=33.3 \%$, calc $=32.6 \%$ ) which is reasonably accounted for by the removal of carbon and 4(CuO), all the thermal diagrams in Figure S12.

\section{Kinetic Studies}

1,1-Oxalyl, 1,1-malonyl and 1,1-succinyl-bis-4-phenyl-thiosemicarbazide and all the metal $\mathrm{Co}(\mathrm{II}), \mathrm{Cu}(\mathrm{II}), \mathrm{Zn}$ (II) and Sn(II) complexes thermodynamic activation parameters of decomposition processes of the samples, namely activation energy, $E^{*}$, enthalpy, $\Delta \mathrm{H}^{*}$, entropy, $\Delta \mathrm{S}^{*}$, and Gibbs free energy change of the decomposition, $\Delta \mathrm{G}^{*}$, were evaluated graphically (Figures S13-S27) by employing the Coats-Redfern and Horowitz-Metzger relations [34]-[36]. All the thermodynamic parameters for the rest of materials, malonyl and Succinyl complexes were also calculated,. All the data for Kinetic thermal studies were summarized in Tables 7-9. The high values of the activation energy illustrated to the thermal stability of the complexes. The activation energies of decomposition 


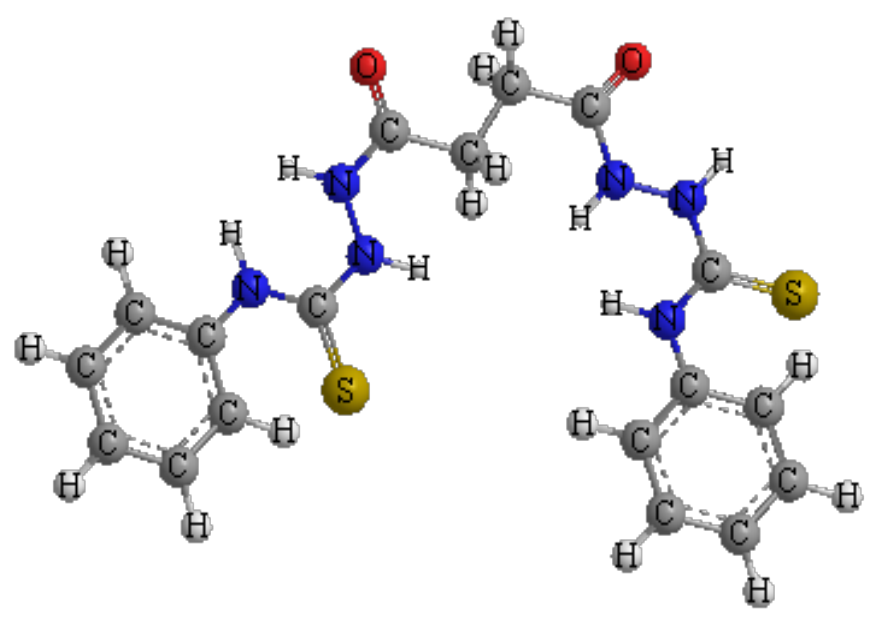

Figure 5. 1,1-Succinyl-bis(4-phenylthiosemicarbazide) (III). Ph-NH-CS-NH$\mathrm{NH}-\mathrm{CO}-\mathrm{CH}_{2}-\mathrm{CH}_{2}-\mathrm{CO}-\mathrm{NH}-\mathrm{NH}-\mathrm{CS}-\mathrm{NH}-\mathrm{Ph}$.

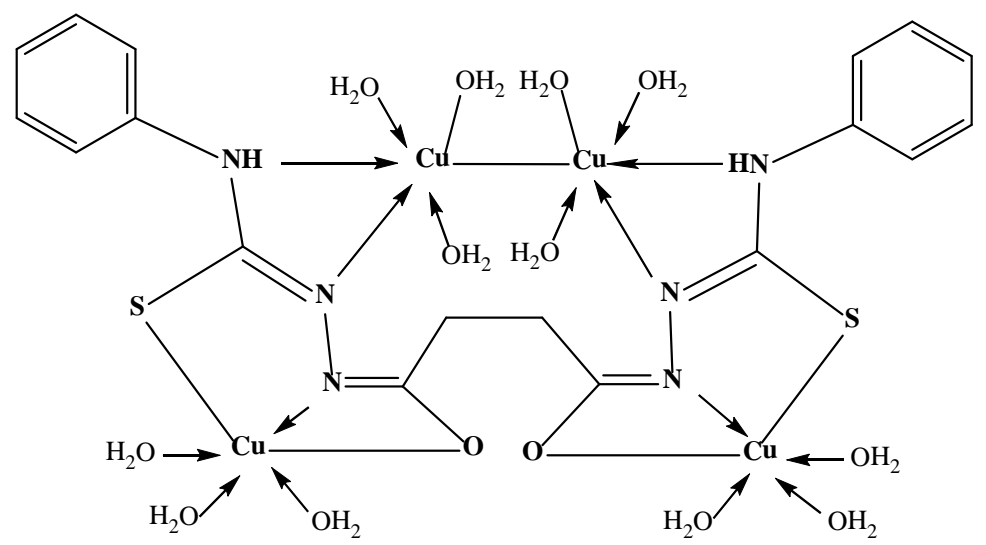

Figure 6. 1,1-Succinyl bis-4-phenylthiosemicarbazide) Tris-copper trihydrate (IIIb).

were in the range $55-450 \mathrm{~kJ} \cdot \mathrm{mol}^{-1}$. The high values of the activation energy illustrated to the thermal stability of the complexes. $\Delta \mathrm{G}$ is positive for reaction for which $\Delta \mathrm{H}$ is positive and $\Delta \mathrm{S}$ is negative. The reaction for which $\Delta \mathrm{G}$ is positive and $\Delta \mathrm{S}$ is negative considered as unfavorable or non spontaneous reactions. Reactions are classified as either exothermic $(\Delta \mathrm{H}<0)$ or endothermic $(\Delta \mathrm{H}>0)$ on the basis of whether they give off or absorb heat. Reactions can also be classified as exergonic $(\Delta \mathrm{G}<0)$ or endergonic $(\Delta \mathrm{G}>0)$ on the basis of whether the free energy of the system decreases or increases during the reaction. The thermodynamic data obtained with the two methods are in harmony with each other. The activation energy of all 1,1-oxalyl-bis (4-phenyl) thiosemicarbazide and its $\mathrm{Co}^{2+}, \mathrm{Cu}^{2+}, \mathrm{Zn}^{2+}$ and $\mathrm{Sn}^{2+}$ complexes is expected to increase in relation with decrease in their radii (Tunali and Ozkar 1993). The smaller size of the ions permits a closer approach of the ligand ( $\mathrm{H}_{4} \mathrm{OxTSC}$ ). Hence, the $\mathrm{E}$ value in the first stage for the $\mathrm{Zn}^{2+}$ complex is higher than that for the other $\mathrm{Sn}^{2+}, \mathrm{Cu}^{2+}$ and $\mathrm{Co}^{2+}$ complex. The correlation coefficients of the Arrhenius plots of the thermal decomposition steps were found to lie in the range 0.9925 to 0.9995 showing a good fit with linear function. It is clear that the thermal decomposition process of all complexes is non-spontaneous, i.e., the thermal stability of the complexes. The activation energy of Ligand $\mathbf{I I}$ and its $\mathrm{Co}^{2+}, \mathrm{Cu}^{2+}, \mathrm{Zn}^{2+}$ and $\mathrm{Sn}^{2+}$ complexes is expected to increase in relation with decrease in their radii. The high values of the activation energy illustrated to the thermal stability of the complexes. The data were calculated and are summarized in Table 8. The smaller size of the ions permits a closer approach of the ligand $\left(\mathrm{H}_{4} \mathrm{MaTSC}\right)$. Hence, the $\mathrm{E}$ value in the first stage for the $\mathrm{Zn}^{2+}$ complex is higher than that for the other $\mathrm{Sn}^{2+}, \mathrm{Cu}^{2+}$ and $\mathrm{Co}^{2+}$ complex. The activation energies of III and its metal complexes are summarized in Table 9. The high values of the activation energy illustrated to the thermal stability of the complexes. It is clear that the 
Table 7. Kinetic parameters using the Coats-Redfern (CR) and Horowitz-Metzger (HM) operated for $\left(\mathrm{H}_{4} \mathrm{OxTS}\right)$ and its complexes.

\begin{tabular}{|c|c|c|c|c|c|c|c|c|}
\hline \multirow[b]{2}{*}{ Complex } & \multirow[b]{2}{*}{ Stage } & \multirow[b]{2}{*}{ Method } & \multicolumn{5}{|c|}{ Parameter } & \multirow[b]{2}{*}{$\mathbf{r}$} \\
\hline & & & $\begin{array}{c}E \\
\left(\mathrm{~J} \mathrm{~mol}^{-1}\right)\end{array}$ & $\underset{\left(s^{-1}\right)}{A}$ & $\begin{array}{c}\Delta \mathrm{S} \\
\left(\mathrm{J} \cdot \mathrm{mol}^{-1} \cdot \mathrm{K}^{-1}\right)\end{array}$ & $\begin{array}{c}\Delta \mathbf{H} \\
\left(\mathrm{J} \cdot \mathbf{m o l}^{-1}\right)\end{array}$ & $\underset{\left(\mathrm{J} \cdot \mathrm{mol}^{-1}\right)}{\Delta \mathrm{G}}$ & \\
\hline (I) & $1^{\text {st }}$ & $\begin{array}{l}\text { CR } \\
\text { HM }\end{array}$ & $\begin{array}{l}1.12 \times 10^{5} \\
1.28 \times 10^{5}\end{array}$ & $\begin{array}{l}1.07 \times 10^{10} \\
1.50 \times 10^{12}\end{array}$ & $\begin{array}{l}-5.68 \times 10^{1} \\
-1.58 \times 10^{1}\end{array}$ & $\begin{array}{l}1.08 \times 10^{5} \\
1.24 \times 10^{5}\end{array}$ & $\begin{array}{l}1.35 \times 10^{5} \\
1.32 \times 10^{5}\end{array}$ & $\begin{array}{l}0.9981 \\
0.9961\end{array}$ \\
\hline (Ia) & $1^{\text {st }}$ & $\begin{array}{l}\text { CR } \\
\text { HM }\end{array}$ & $\begin{array}{l}5.14 \times 10^{4} \\
6.33 \times 10^{4}\end{array}$ & $\begin{array}{l}7.99 \times 10^{3} \\
6.60 \times 10^{3}\end{array}$ & $\begin{array}{l}-1.75 \times 10^{2} \\
-1.77 \times 10^{2}\end{array}$ & $\begin{array}{l}4.68 \times 10^{4} \\
5.87 \times 10^{4}\end{array}$ & $\begin{array}{l}1.43 \times 10^{5} \\
1.56 \times 10^{5}\end{array}$ & $\begin{array}{l}0.9920 \\
0.9929\end{array}$ \\
\hline (Ib) & $1^{\text {st }}$ & $\begin{array}{l}\text { CR } \\
\text { HM }\end{array}$ & $\begin{array}{l}1.10 \times 10^{5} \\
1.31 \times 10^{5}\end{array}$ & $\begin{array}{c}7.01 \times 10^{9} \\
2.96 \times 10^{12}\end{array}$ & $\begin{array}{l}-6.04 \times 10^{1} \\
-1.01 \times 10^{1}\end{array}$ & $\begin{array}{l}1.06 \times 10^{5} \\
1.27 \times 10^{5}\end{array}$ & $\begin{array}{l}1.35 \times 10^{5} \\
1.31 \times 10^{5}\end{array}$ & $\begin{array}{l}0.9995 \\
0.9991\end{array}$ \\
\hline (Ic) & $1^{\text {st }}$ & $\begin{array}{l}\text { CR } \\
\text { HM }\end{array}$ & $\begin{array}{l}8.04 \times 10^{4} \\
1.07 \times 10^{5}\end{array}$ & $\begin{array}{l}7.21 \times 10^{5} \\
2.29 \times 10^{8}\end{array}$ & $\begin{array}{l}-1.38 \times 10^{2} \\
-8.98 \times 10^{1}\end{array}$ & $\begin{array}{l}7.59 \times 10^{4} \\
1.02 \times 10^{5}\end{array}$ & $\begin{array}{l}1.50 \times 10^{5} \\
1.51 \times 10^{5}\end{array}$ & $\begin{array}{l}0.9968 \\
0.9985\end{array}$ \\
\hline (Id) & $1^{\text {st }}$ & $\begin{array}{l}\text { CR } \\
\text { HM }\end{array}$ & $\begin{array}{l}8.61 \times 10^{4} \\
1.71 \times 10^{5}\end{array}$ & $\begin{array}{c}1.65 \times 10^{7} \\
32.75 \times 10^{9}\end{array}$ & $\begin{array}{l}-1.11 \times 10^{2} \\
-6.59 \times 10^{1}\end{array}$ & $\begin{array}{c}8.2 \times 10^{4} \\
1.05 \times 10^{5}\end{array}$ & $\begin{array}{l}1.37 \times 10^{5} \\
1.38 \times 10^{5}\end{array}$ & $\begin{array}{l}0.9938 \\
0.9955\end{array}$ \\
\hline
\end{tabular}

Table 8. Kinetic parameters using the Coats-Redfern (CR) and Horowitz-Metzger (HM) operated for: ( $\left.\mathrm{H}_{4} \mathrm{MaTS}\right)$ and its $\mathrm{Co}(\mathrm{II}), \mathrm{Cu}(\mathrm{II}), \mathrm{Zn}(\mathrm{II})$ and $\mathrm{Sn}(\mathrm{II})$ complexes.

\begin{tabular}{|c|c|c|c|c|c|c|c|c|}
\hline \multirow[b]{2}{*}{ Complex } & \multirow[b]{2}{*}{ Stage } & \multirow[b]{2}{*}{ Method } & \multicolumn{5}{|c|}{ Parameter } & \multirow[b]{2}{*}{$\mathbf{r}$} \\
\hline & & & $\begin{array}{c}E \\
\left(\mathrm{~J} \cdot \mathrm{mol}^{-1}\right)\end{array}$ & $\underset{\left(s^{-1}\right)}{A}$ & $\begin{array}{c}\Delta S \\
\left(\mathbf{J} \cdot \mathbf{m o l}^{-1} \cdot \mathbf{K}^{-1}\right)\end{array}$ & $\underset{\left(\mathrm{J} \cdot \mathrm{mol}^{-1}\right)}{\Delta \mathbf{H}}$ & $\underset{\left(\mathrm{J} \cdot \mathbf{m o l}^{-1}\right)}{\Delta \mathrm{G}}$ & \\
\hline (II) & $1^{\text {st }}$ & $\begin{array}{l}\text { CR } \\
\text { HM }\end{array}$ & $\begin{array}{l}1.79 \times 10^{5} \\
1.54 \times 10^{5}\end{array}$ & $\begin{array}{l}1.94 \times 10^{17} \\
7.15 \times 10^{14}\end{array}$ & $\begin{array}{l}8.20 \times 10^{1} \\
3.54 \times 10^{1}\end{array}$ & $\begin{array}{l}1.75 \times 10^{5} \\
1.50 \times 10^{5}\end{array}$ & $\begin{array}{l}1.35 \times 10^{5} \\
1.33 \times 10^{5}\end{array}$ & $\begin{array}{l}0.9997 \\
0.9992\end{array}$ \\
\hline (IIa) & $1^{\text {st }}$ & $\begin{array}{l}\text { CR } \\
\text { HM }\end{array}$ & $\begin{array}{l}4.70 \times 10^{4} \\
6.65 \times 10^{4}\end{array}$ & $\begin{array}{l}1.40 \times 10^{2} \\
4.13 \times 10^{4}\end{array}$ & $\begin{array}{l}-2.08 \times 10^{2} \\
-1.61 \times 10^{2}\end{array}$ & $\begin{array}{l}4.27 \times 10^{4} \\
6.22 \times 10^{4}\end{array}$ & $\begin{array}{l}1.50 \times 10^{5} \\
1.45 \times 10^{5}\end{array}$ & $\begin{array}{l}0.9963 \\
0.9956\end{array}$ \\
\hline (IIb) & $1^{\text {st }}$ & $\begin{array}{l}\text { CR } \\
\text { HM }\end{array}$ & $\begin{array}{l}6.07 \times 10^{4} \\
6.87 \times 10^{4}\end{array}$ & $\begin{array}{l}2.32 \times 10^{3} \\
2.35 \times 10^{4}\end{array}$ & $\begin{array}{l}-1.86 \times 10^{2} \\
-1.66 \times 10^{2}\end{array}$ & $\begin{array}{l}5.61 \times 10^{4} \\
6.42 \times 10^{4}\end{array}$ & $\begin{array}{l}1.58 \times 10^{5} \\
1.55 \times 10^{5}\end{array}$ & $\begin{array}{l}0.9931 \\
0.9918\end{array}$ \\
\hline (IIc) & $1^{\text {st }}$ & $\begin{array}{l}\text { CR } \\
\text { HM }\end{array}$ & $\begin{array}{l}4.58 \times 10^{4} \\
4.65 \times 10^{5}\end{array}$ & $\begin{array}{l}1.17 \times 10^{47} \\
1.20 \times 10^{48}\end{array}$ & $\begin{array}{l}6.52 \times 10^{2} \\
6.70 \times 10^{2}\end{array}$ & $\begin{array}{l}4.54 \times 10^{5} \\
4.61 \times 10^{5}\end{array}$ & $\begin{array}{l}1.33 \times 10^{5} \\
1.30 \times 10^{5}\end{array}$ & $\begin{array}{l}0.9977 \\
0.9982\end{array}$ \\
\hline (IId) & $1^{\text {st }}$ & $\begin{array}{l}\text { CR } \\
\text { HM }\end{array}$ & $\begin{array}{l}2.76 \times 10^{4} \\
2.95 \times 10^{5}\end{array}$ & $\begin{array}{l}1.68 \times 10^{27} \\
1.77 \times 10^{29}\end{array}$ & $\begin{array}{l}2.72 \times 10^{2} \\
3.11 \times 10^{2}\end{array}$ & $\begin{array}{l}2.72 \times 10^{5} \\
2.90 \times 10^{5}\end{array}$ & $\begin{array}{l}1.36 \times 10^{5} \\
1.35 \times 10^{5}\end{array}$ & $\begin{array}{l}0.9950 \\
0.9945\end{array}$ \\
\hline
\end{tabular}

Table 9. Kinetic parameters using the Coats-Redfern (CR) and Horowitz-Metzger (HM) operated for 1,1-succinyl-bis (phenylthiosemicarbazide) and its Co(II), Cu(II), Zn(II) and Sn(II) complexes.

\begin{tabular}{|c|c|c|c|c|c|c|c|c|}
\hline \multirow[b]{2}{*}{ Complex } & \multirow[b]{2}{*}{ Stage } & \multirow[b]{2}{*}{ Method } & \multicolumn{5}{|c|}{ Parameter } & \multirow[b]{2}{*}{$\mathbf{r}$} \\
\hline & & & $\begin{array}{c}E \\
\left(\mathrm{~J} \cdot \mathrm{mol}^{-1}\right)\end{array}$ & $\underset{\left(\mathrm{s}^{-1}\right)}{A}$ & $\begin{array}{c}\Delta \mathrm{S} \\
\left(\mathrm{J} \cdot \mathrm{mol}^{-1} \cdot \mathrm{K}^{-1}\right)\end{array}$ & $\underset{\left(\mathrm{J} \cdot \mathbf{m o l}^{-1}\right)}{\Delta \mathbf{H}}$ & $\underset{\left(\mathrm{J} \cdot \mathbf{m o l}^{-1}\right)}{\Delta \mathrm{G}}$ & \\
\hline (III) & $1^{\text {st }}$ & $\begin{array}{l}\text { CR } \\
\text { HM }\end{array}$ & $\begin{array}{l}3.23 \times 10^{5} \\
3.51 \times 10^{5}\end{array}$ & $\begin{array}{l}1.82 \times 10^{33} \\
2.96 \times 10^{36}\end{array}$ & $\begin{array}{l}3.88 \times 10^{2} \\
4.49 \times 10^{2}\end{array}$ & $\begin{array}{l}3.19 \times 10^{5} \\
3.47 \times 10^{5}\end{array}$ & $\begin{array}{l}1.31 \times 10^{5} \\
1.29 \times 10^{5}\end{array}$ & $\begin{array}{l}0.9984 \\
0.9989\end{array}$ \\
\hline (IIIa) & $1^{\text {st }}$ & $\begin{array}{l}\text { CR } \\
\text { HM }\end{array}$ & $\begin{array}{l}4.56 \times 10^{4} \\
5.49 \times 10^{4}\end{array}$ & $\begin{array}{l}1.31 \times 10^{2} \\
2.02 \times 10^{3}\end{array}$ & $\begin{array}{l}-2.09 \times 10^{2} \\
-1.86 \times 10^{2}\end{array}$ & $\begin{array}{l}4.13 \times 10^{4} \\
5.05 \times 10^{4}\end{array}$ & $\begin{array}{l}1.50 \times 10^{5} \\
1.47 \times 10^{5}\end{array}$ & $\begin{array}{l}0.9988 \\
0.9953\end{array}$ \\
\hline (IIIb) & $3^{\text {st }}$ & $\begin{array}{l}\text { CR } \\
\text { HM }\end{array}$ & $\begin{array}{l}1.67 \times 10^{5} \\
2.13 \times 10^{5}\end{array}$ & $\begin{array}{l}5.30 \times 10^{5} \\
5.28 \times 10^{7}\end{array}$ & $\begin{array}{l}-1.46 \times 10^{2} \\
-1.08 \times 10^{2}\end{array}$ & $\begin{array}{l}1.57 \times 10^{5} \\
2.04 \times 10^{5}\end{array}$ & $\begin{array}{l}3.20 \times 10^{5} \\
3.24 \times 10^{5}\end{array}$ & $\begin{array}{l}0.9993 \\
0.9985\end{array}$ \\
\hline (IIIc) & $1^{\text {st }}$ & $\begin{array}{l}\text { CR } \\
\text { HM }\end{array}$ & $\begin{array}{l}1.95 \times 10^{5} \\
2.06 \times 10^{5}\end{array}$ & $\begin{array}{l}5.85 \times 10^{18} \\
1.77 \times 10^{20}\end{array}$ & $\begin{array}{l}1.10 \times 10^{2} \\
1.39 \times 10^{2}\end{array}$ & $\begin{array}{l}1.91 \times 10^{5} \\
2.02 \times 10^{5}\end{array}$ & $\begin{array}{l}1.37 \times 10^{5} \\
1.34 \times 10^{5}\end{array}$ & $\begin{array}{l}0.9992 \\
0.9974\end{array}$ \\
\hline (IIId) & $1^{\text {st }}$ & $\begin{array}{l}\text { CR } \\
\text { HM }\end{array}$ & $\begin{array}{l}8.08 \times 10^{4} \\
9.84 \times 10^{4}\end{array}$ & $\begin{array}{l}3.72 \times 10^{6} \\
2.60 \times 10^{8}\end{array}$ & $\begin{array}{l}-1.23 \times 10^{2} \\
-8.81 \times 10^{1}\end{array}$ & $\begin{array}{l}7.66 \times 10^{4} \\
9.43 \times 10^{4}\end{array}$ & $\begin{array}{l}1.38 \times 10^{5} \\
1.38 \times 10^{5}\end{array}$ & $\begin{array}{l}0.9984 \\
0.9984\end{array}$ \\
\hline
\end{tabular}

thermal decomposition process of compounds I, II, III and $\mathrm{Co}^{2+}, \mathrm{Cu}^{2+}, \mathrm{Zn}^{2+}, \mathrm{Sn}^{2+}$ metal complexes are non-spontaneous, i.e., the materials are thermally stable.

\section{Antimicrobial Activity}

Three compounds were tested in vitro for their antibacterial activities against four strains of bacteria Gram nega- 
tive Escherichia coli, Pseudomonas aeruginosa species and gram-positive Bacillus cereus and Staphylococcus aureus. The bacteria were maintained on nutrient agar media. The minimal inhibitory concentration of some of the tested compounds was measured by a threefold serial dilution method. The screening results indicate that not all the compounds exhibited antibacterial activities. In this study, the tested compounds oxalyl, malonyl, and succinyl bis-4-phenylthiosemicarbazide were active against both Bacillus cereus, Staphylococcus aureus which are Gram-positive bacteria as well as Escherichia coli and Pseudomons aeruginose which are Gram-negative bacteria. However, the antibacterial activity was very pronounced against the Gram-negative bacteria and could be classified in the order of very good activity.

\section{Conclusion}

The activation energies of decomposition of 1,1-oxalyl, 1,1-malonyl and 1,1-succinyl-bis-4-phenyl-thiosemicarbazide and all the metal complexes are calculated. The data are summarized in Tables 7-9. The high values of the activation energy are illustrated to the thermal stability of the complexes. It is clear that the thermal decomposition process of all 1,1-oxalyl-bis-4-phenylthiosemicarbazide $\left(\mathrm{H}_{4} \mathrm{OxTSC}\right)$ and its complexes is thermally stable. The activation energy of Ligand $\mathbf{I I}$ and its $\mathrm{Co}^{2+}, \mathrm{Cu}^{2+}, \mathrm{Zn}^{2+}$ and $\mathrm{Sn}^{2+}$ complexes are expected to increase in relation with decrease in their radii. The high values of the activation energy are illustrated to the thermal stability of the complexes. The data are calculated and are summarized in Table 7, Table 8 . The smaller size of the ions permits a closer approach of the ligand $\left(\mathrm{H}_{4}\right.$ MaTSC). Hence, the $\mathrm{E}$ value in the first stage for the $\mathrm{Zn}^{2+}$ complex is higher than that for the other $\mathrm{Sn}^{2+}, \mathrm{Cu}^{2+}$ and $\mathrm{Co}^{2+}$ complex. The activation energies of III and its metal complexes are summarized in Table 9. The high values of the activation energy are illustrated to the thermal stability of the complexes. It is clear that the thermal decomposition process of compounds I, II, III and $\mathrm{Co}^{2+}$, $\mathrm{Cu}^{2+}, \mathrm{Zn}^{2+}, \mathrm{Sn}^{2+}$ metal complexes are non-spontaneous, i.e., the materials are thermally stable. The tested compound I, II and III show a good activity against four strains of bacteria Gram negative Escherichia coli, Pseudomonas aeruginosa species and Gram-positive Bacillus cereus and Staphylococcus aureus.

\section{References}

[1] Preston, J.B. (1955) Pentylenetetrazole AND Thiosemicarbazide: A Study of Convulsant Activity in the Isolated Cerebral Cortex Preparation, Journal of Pharmacology.

[2] DeConti, R.C., Toftness, B.R., Agrawal, K.C., et al. (1972) Clinical and Pharmacological Studies with 5-Hydroxy-2formylpyridine Thiosemicarbazone. Cancer Research, 32, 1455-1462.

[3] Lobana, T.S., Butcher, R.J., Castineiras, A., Bermejo, E. and Bharatam, Prasad V. (2006) Bonding Trends of Thiosemicarbazones in Mononuclear and Dinuclear Copper(I) Complexes: Syntheses, Structures, and Theoretical Aspects. Inorganic Chemistry, 45, 1535-1542.

[4] Zhao, Y. (2000) Liquid Chromatographic Determination of Chelates of Cobalt(II), Copper(II) and Iron(II) with 2-Thiophenecarboxaldehyde-4-phenyl-3-thiosemicarbazone. Chromatographia, 51, 231-234. http://dx.doi.org/10.1007/BF02490570

[5] Khuhawar, M.Y. and Lanjwani, S.N. (1998) Liquid Chromatographic Determination of Cobalt(II), Copper(II) and Iron(II) Using 2-Thiophenaldehyde-4-phenyl-3-thiosemicarbazone as Derivatizing Reagent. Talanta, 46, 485-490. http://dx.doi.org/10.1016/S0039-9140(97)00213-0

[6] Lunn, G., Phillips, L.R. and Pacula-Cox, C. (1998) Reversed-Phase High-Performance Liquid Chromatography of 4-(2-Pyridyl)-1-piperazinethiocarboxylic Acid 2-[1-(Pyridyl)ethylidene]hydrazide dihydrochloride (NSC 348977), a Synthetic Thiosemicarbazone with Antitumor Activity. Journal of Chromatography B: Biomedical Sciences and Applications, 708, 217-222. http://dx.doi.org/10.1016/S0378-4347(97)00637-3

[7] Hoshi, S., Higashihara, K., Suzuki, M., Sakurada, Y., Sugawara, K., Uto, M. and Akatsuka, K. (1997) Simultaneous Determination of Platinum(II) and Palladium(II) by Reversed Phase High-Performance Liquid Chromatography with Spectrophotometric Detection after Collection on and Elution from Resin Coated with Dimethylglyoxal Bis (4-phenyl3-thisomicarbazone). Talanta, 44, 571-576. http://dx.doi.org/10.1016/S0039-9140(96)02064-4

[8] Gismera, M.J., Mendiola, M.A., Procopio, J.R. and Sevilla, M.T. (1999) Copper Potentiometric Sensors Based on Copper Complexes Containing Thiohydrazone and Thiosemicarbazone Ligands. Analytica Chimica Acta, 385, $143-149$. http://dx.doi.org/10.1016/S0003-2670(98)00840-X

[9] Qu, J.Y., Liu, M. and Liu, K.Z. (1999) Simultaneous Determination of Lead and Copper by Carbon Paste Electrodes Modified with Pyruvaldehyde Bis(NN’-Dibutyl Thiosemicarbazone). Analytical Letters, 32, 1991-2006. http://dx.doi.org/10.1080/00032719908542947 
[10] Tang, B., Du, M., Sun, Y., Xu, H.L. and Shen, H.X. (1998) The Study and Application of Biomimic Peroxidase Ferric 2-Hydroxy-1-naphthaldehyde Thiosemicarbazone. Talanta, 47, 361-366. http://dx.doi.org/10.1016/S0039-9140(98)00149-0

[11] West, D.X., Carlson, C.S., Liberta, A.E. and Scovil, J.P. (1990) The Chemical and Antifungal Properties of the Copper (II) Complexes of 2-Acetyl-pyrazine ${ }^{4} \mathrm{~N}$-methyl-, ${ }^{4} \mathrm{~N}$-dimethyl-, and 3-Hexamethyleneiminyl-thiosemicarbazone. Trans. Metchem, 15, 383-387. http://dx.doi.org/10.1007/BF01177467

[12] West, D.X., Carlson, C.S., Liberta, A.E., Albert, J.N. and Daniel, C.R. (1990) Transtion Metal Ion Complexes of Thiosemicarbazones Derived from 2-Acetylpyridine. Transition Metal Chemistry, 15, 341-344. http://dx.doi.org/10.1007/BF01177458

[13] Mandour, A.H., Fawzy, N.M., El-Shihi, T.H. and El-Bazza, Z.E. (1995) Synthesis, Antimicrobial and Antiaflatoxigenic Activities of Some Benzofuran Containing 1,2,4-Triazole, 1,3,4-Thiadiazole and Oxadiazole Derivatives. Pakistan Journal of Scientific and Industrial Research, 38, 402-406.

[14] Liu, M.C., Lin, T.S., Penketh, P. and Sartorelli, A.C. (1995) Synthesis and Antitumor Activity of 4- and 5-Substituted Derivatives of Isoquinoline-1-carboxaldehyde Thiosmicarbazone. Journal of Medicinal Chemistry, 38, 4234-4243. http://dx.doi.org/10.1021/jm00021a012

[15] Liu, M.C., Lin, T.S., Cory, J.G., Cory, A.H. and Sartorelli, A.C. (1996) Synthesis and Biological Activity of 3- and 5-Amino Derivatives of Pyridine-2-carboxaldehyde Thiosemicarbazone. Journal of Medicinal Chemistry, 39, 25862593. http://dx.doi.org/10.1021/jm9600454

[16] Zhu, X., Wang, C., Lu, Z., Dang, Y. (1997) Synthesis Characterization and Biological Activity of the Schiffbase Derived from 3,4-Dihydroxybenz-aldehyde and Thiosemicarbazide, and Its Metal Complexes with Nickel(II) and Iron(II). Transition Metal Chemistry (London), 22, 9-13. http://dx.doi.org/10.1023/A:1018453316348

[17] Lim, J.K., Mathias, C.J. and Green, A.M.J. (1997) Mixed Bis(thiosemicarbazone) Ligands for the Preparation of Copper Radiopharmaceuticals: Synthesis and Evaluation of Tetradentate Ligands Containing Two Dissimilar Thiosemicarbazone Functions. Journal of Medicinal Chemistry, 40, 132-136. http://dx.doi.org/10.1021/jm9605703

[18] Amin, R.R., Yamany, Y.B., Abo-Aly, M.M. and Hassan, A.M.A. (2011) Kinetic Parameters for Thermal Decomposition for Novel 1,1-Malonyl bis(4-p-chlorophenylthiosemicarbazide and $\mathrm{Cu}(\mathrm{II}), \mathrm{Co}(\mathrm{II}), \mathrm{Zn}(\mathrm{II})$ and Sn(II) Complexes Synthesized by Electrochemical Method. Natural Science, 3, 783-794. http://dx.doi.org/10.4236/ns.2011.39103

[19] El-Shekeil, A., Al-Yusufy, F., Amin, R.R. and Abdullah, A.-H. (2004) The DC Electrical Conductivity of the Direct Electrochemically Synthesized Poly (Azomethinethiosemicarbazone)-Metal Complexes. Journal of Inorganic and Organometallic Polymers, 14, 131-148. http://dx.doi.org/10.1023/B:JOIP.0000028091.50660.3a

[20] El-Asmy, A.A., Al-Ansi, T.Y., Amin, R.R. and El-Shahat, M.F. (1990) Structural Studies on Cadmium(II), Cobalt(II), Copper(II) Nickel(II) and Zinc(II) Complexes of 1-Malonyl bis(4-phenylthiosemicarbazide). Transition Metal Chemistry, 15, 12-15.

[21] El-Asmy, A.A., Al-Ansi, T.Y., Amin, R.R. and Mounir, M. (1990) Spectral, Magnetic and Electrical Properties of 1Succinyl Bis(4-phenylthiosemicarbazide) Complexes. Polyhedron, 9, 2029-2034. http://dx.doi.org/10.1016/S0277-5387(00)84032-2

[22] Mostafa, M.M. (2007) Spectroscopic Studies of Some Thiosemicarbazide Compounds Derived from Girard's T and P. Spectrochimica Acta Part A: Molecular and Biomolecular Spectroscopy, 66, 480-486. http://dx.doi.org/10.1016/j.saa.2006.02.063

[23] Elreedy, A.A.M. and Amin, R.R. (2015) Chemical and Electrochemical Preparation for Some Metal(II) Complexes of Some Pyridine-2-(1H)-thione-3-cyano-4-(2-methylphenyl)-5,6-Ring. Fused Cycloalkane Derivatives, 6.

[24] Amin, R.R. and El-Gemeie, G.E.H. (2001) The Direct Electrochemical Synthesis of Co(II), Ni(II) and Cu(II) Complexes of Some Pyridinethione Derivatives. Synthesis and Reactivity in Inorganic and Metal-Organic Chemistry, 31, 431-440. http://dx.doi.org/10.1081/SIM-100002230

[25] El-Metwally, N.M., El-Shazly, R.M., Gabr, I.M. and El-Asmy, A.A. (2005) Physical and Spectroscopic Studies on Novel Vanadyl Complexes of Some Substituted Thiosemicarbazides. Spectrochimica Acta Part A: Molecular and Biomolecular Spectroscopy, 61, 1113-1119. http://dx.doi.org/10.1016/j.saa.2004.06.027

[26] Novaković, S.B., Bogdanović, G.A. and Leovac, V.M. (2006) Transition Metal Complexes with ThiosemicarbazideBased Ligands. Part L. Synthesis, Physicochemical Properties and Crystal Structures of Co(II) Complexes with Acetone S-Methyliso-Thiosemicarbazone. Polyhedron, 25, 1096-1104.

[27] Novaković, S.B., Bogdanović, G.A. and Leovac, V.M. (2005) Transition Metal Complexes with ThiosemicarbazideBased Ligands. XLIV. The Supramolecular Arrangement in the Ni(II) Complexes of S-Methylisothiosemicarbazide. Inorganic Chemistry Communications, 8, 9-13.

[28] Leovac, V.M., Novaković, S.B., Bogdanović, G.A., Joksović, M.D. and Mészáros, K. (2007) Transition Metal Complexes 
with Thiosemicarbazide-Based Ligands. Part LVI: Nickel(II) Complex with 1,3-Diphenylpyrazole-4-carboxaldehyde Thiosemicarbazone and Unusually Deformed Coordination Geometry. Polyhedron, 26, 3783-3792. http://dx.doi.org/10.1016/j.poly.2007.04.012

[29] Refat, M., Al-Azab, F., Mudamma, H., Amin, R.R. and Jameel, Y. (2014) Preparation, Spectroscopic and Thermal Characterization of New La(III), Ce(III), Sm(III) and Y(III) Complexes of Enalapril Maleate Drug. In Vitro Antimicrobial Assessment Studies. Journal of Molecular Structure, 1059, 208-224. http://dx.doi.org/10.1016/j.molstruc.2013.12.003

[30] El-Asmy, A.A., Al-Gammal, O.A., Dena, A.S. and Ghazy, S.E. (2009) Synthesis, Characterization, Molecular Modeling and Eukaryotic DNA Degradation of 1-(3,4-Dihydroxybenzylidene) Thiosemicarbazide Complexes. Journal of Molecular Structure, 934, 9-22. http://dx.doi.org/10.1016/j.molstruc.2009.05.039

[31] Hassaneien, M.M., Gabr, I.M., Abdel-Rhman, M.H. and El-Asmy, A.A. (2008) Synthesis and Structural Investigation of Mono- and Polynuclear Copper Complexes of 4-Ethyl-1-(pyridin-2-yl) Thiosemicarbazide. Spectrochimica Acta Part A, 71, 73-79. http://dx.doi.org/10.1016/j.saa.2007.11.009

[32] Chandra, S. and Kumar, U. (2005) Spectral and Magnetic Studies on Manganese(II), Cobalt(II) and Nickel(II) Complexes with Schiff Bases. Spectrochimica Acta, Part A, 61, 219-224. http://dx.doi.org/10.1016/j.saa.2004.03.036

[33] Chohan, Z.H. (2009) Metal-Based Antibacterial and Antifungal Sulfonamides: Synthesis, Characterization, and Biological Properties. Transition Metal Chemistry, 34, 153-161. http://dx.doi.org/10.1007/s11243-008-9171-y

[34] Refat, M.S., El-Deen, I.M., Amin, R.R. and El-Ghol, S. (2010) Spectroscopic Studies and Biological Evaluation of Some Transition Metal Complexes of a Novel Schiff Base Ligands Derived From 5-Arylazo-Salicyladehyde and O-Amino Phenol. Toxicological \& Environmental Chemistry, 92, 1093-1110. http://dx.doi.org/10.1080/02772240903252173

[35] Refat, M.S., Al-Maydama, H.M.A., Al-Azab, F., Amin, R.R. and Jamil, Y.M.S. (2014) Synthesis, Thermal and Spectroscopic Behaviors of Metal-Drug Complexes: La(III), Ce(III), Sm(III) and Y(III) Amoxicillin Trihydrate Antibiotic Drug Complexes. Spectrochimica Acta Part A: Molecular and Biomolecular Spectroscopy, 128, 427-446.

[36] Refat, M., Amin, R.R., Jameel, Y., Al-Azab, F. and Mudam, H. (2014) Synthesis and in Vitro Microbial Evaluation of La(III), Ce(III), Sm(III) and Y(III) Metal Complexes of Vitamin B6 Drug. Spectrochimica Acta Part A: Molecular and Biomolecular Spectroscopy, 127, 196-215. http://dx.doi.org/10.1016/j.saa.2014.02.043 


\section{Appendix}

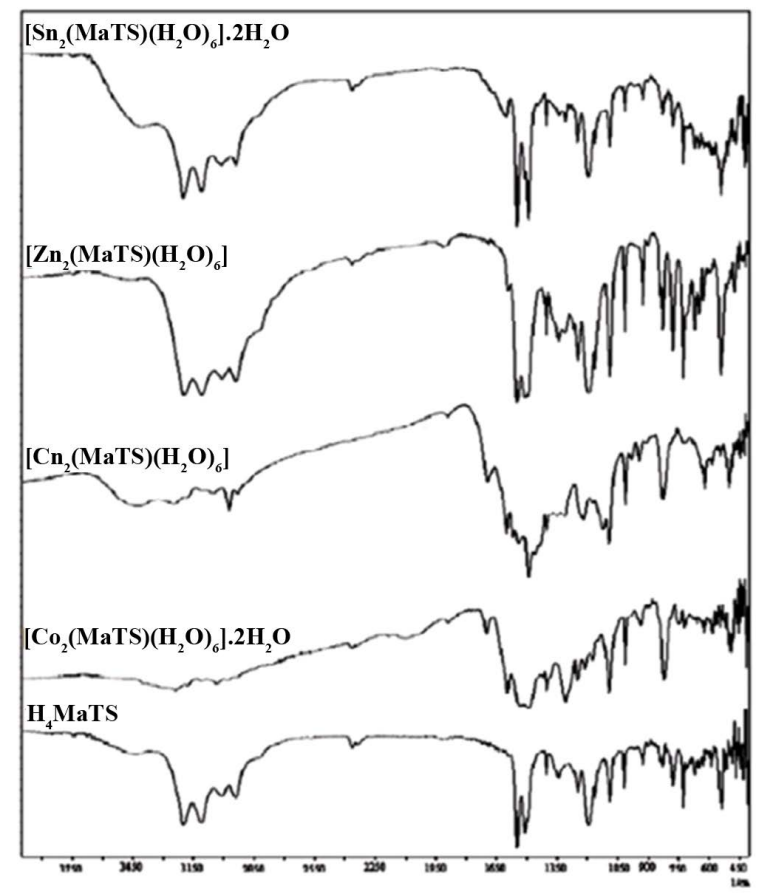

Figure S1. IR spectra for 1, 1-Malonyl bis-4phenyl thiosemicarbazide and its metal complexes.

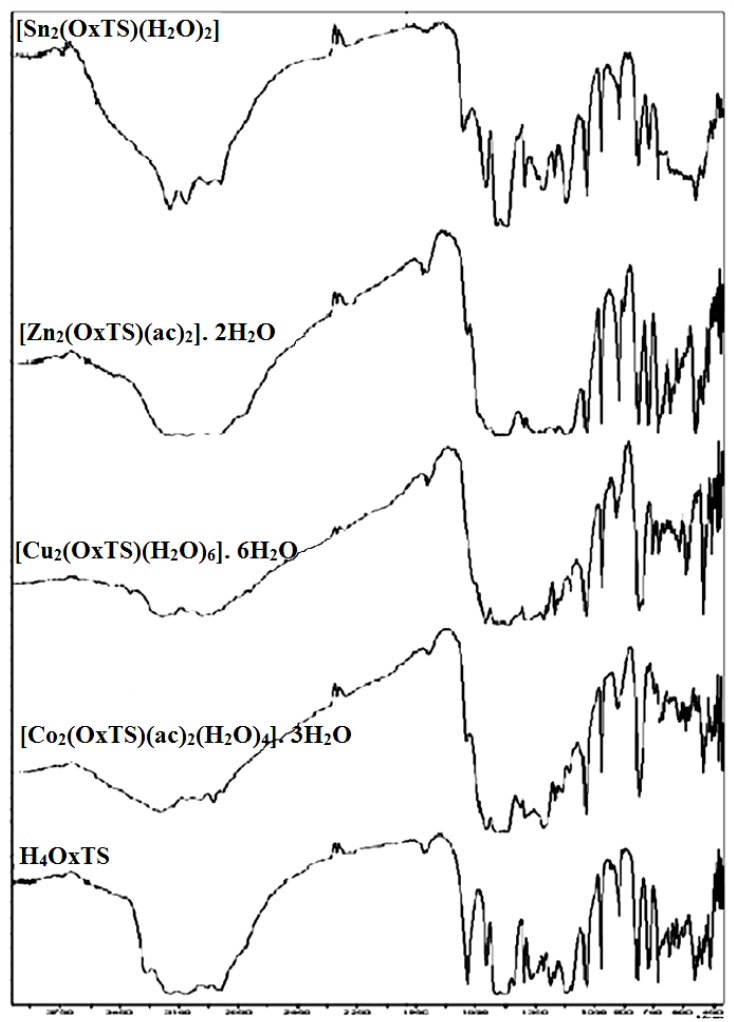

Figure S2. IR spectra for 1,1-Oxalyl bis-4phenyl thiosemicarbazide and its metal complexes. 


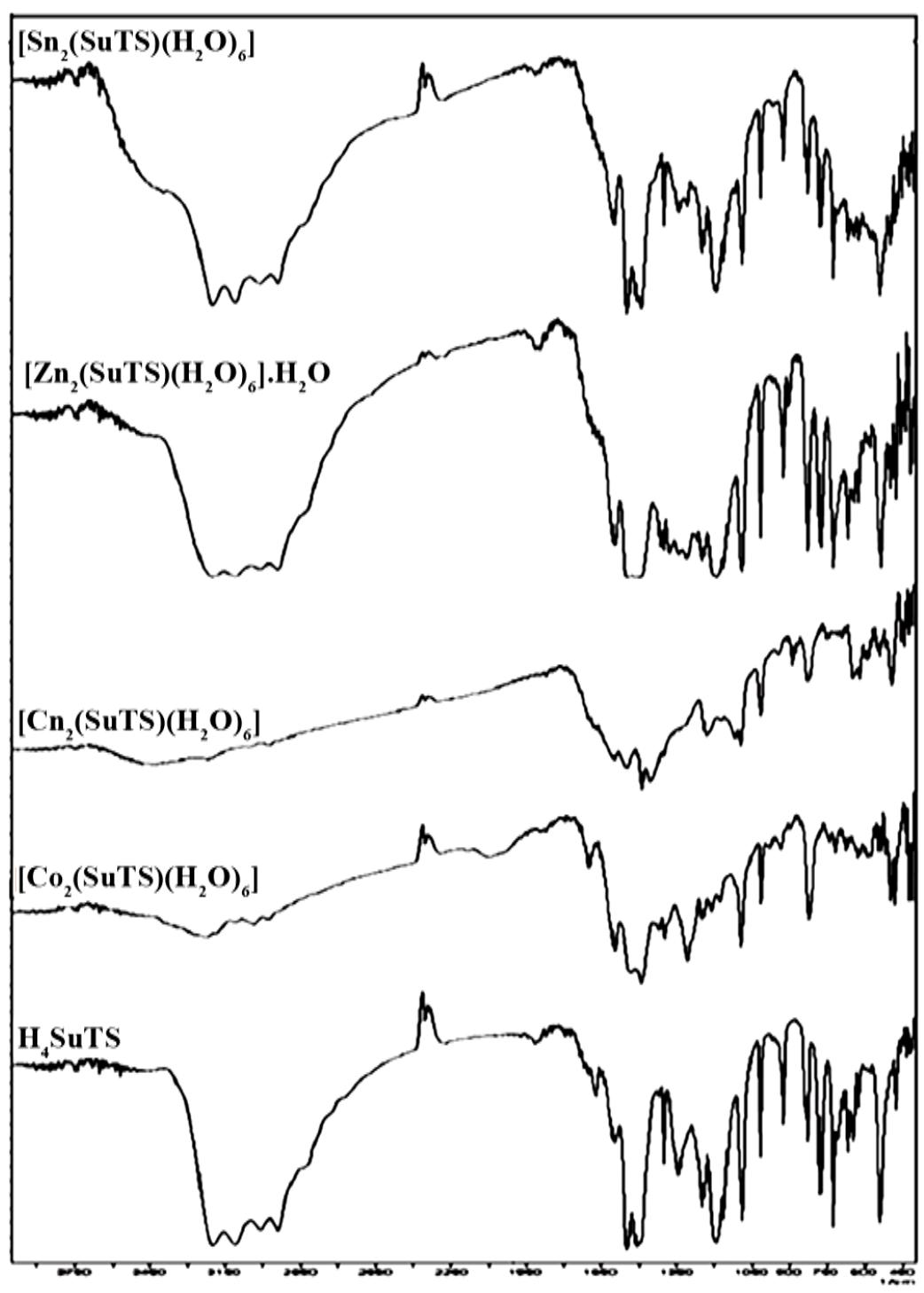

Figure S3. IR spectra for 1, 1-Succinyl bis-4phenyl thiosemicarbazide and its metal complexes.

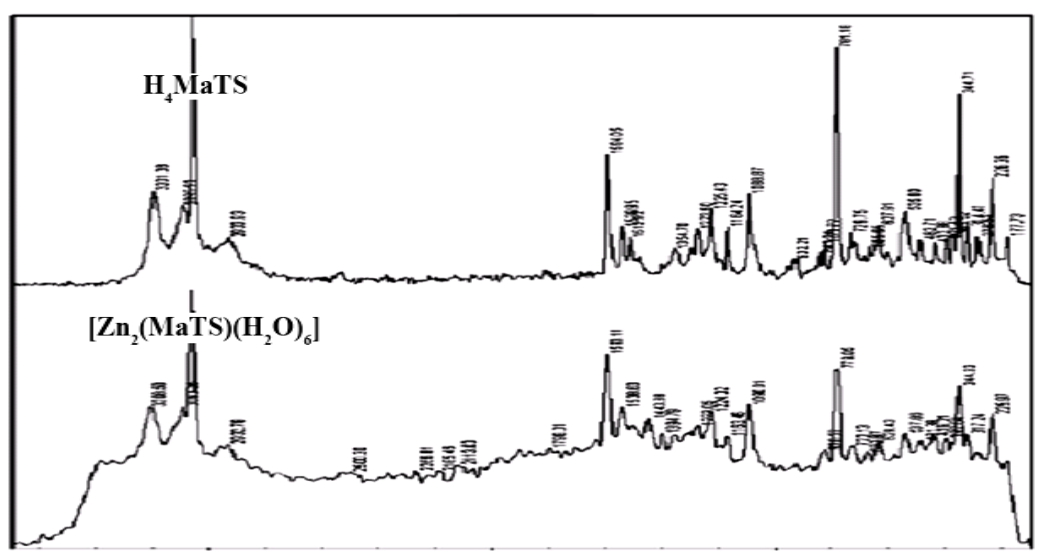

Figure S4. Raman spectra for 1, 1-Malonylbis-4phenyl thiosemicarbazide and Zinc-metal complex. 


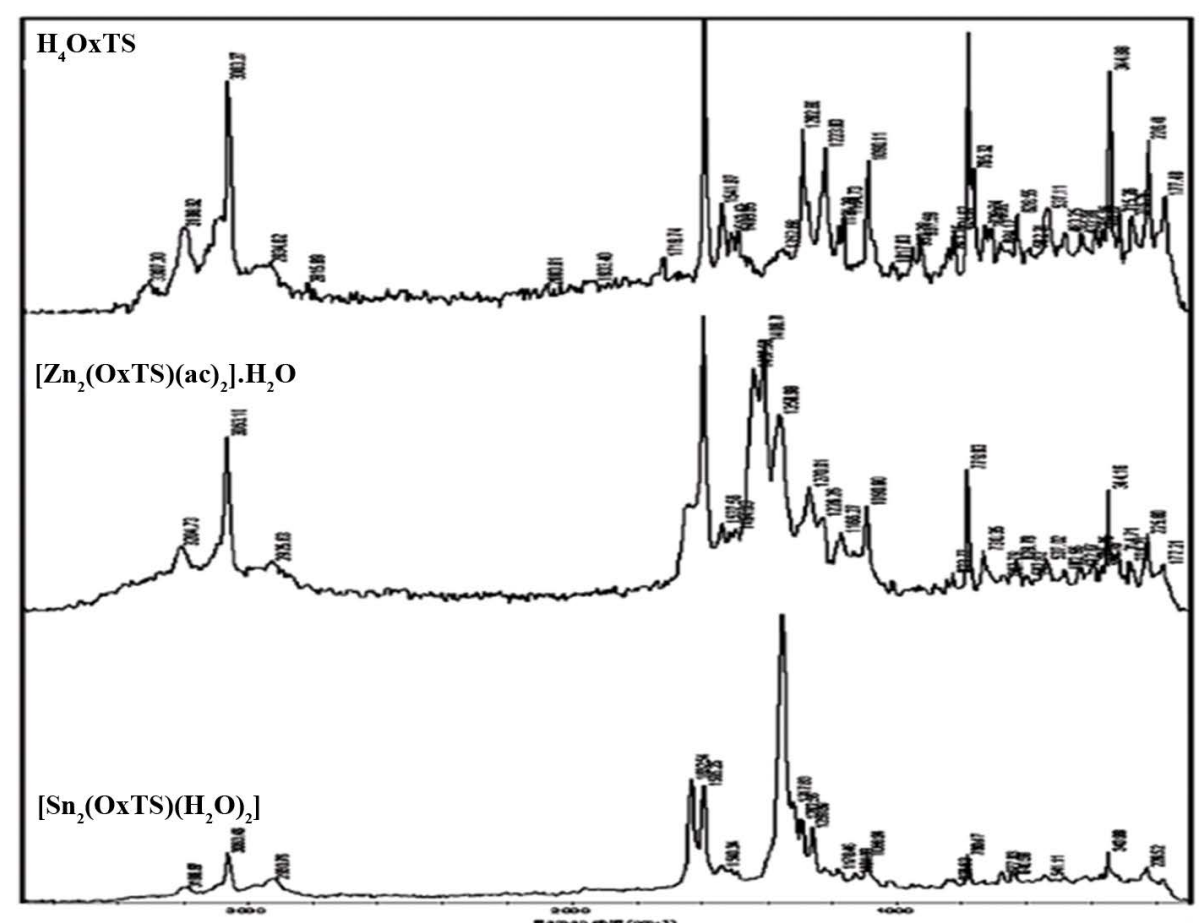

Figure S5. Raman spectra for 1, 1-Oxalaylbis-4phenylthiosemicarbazide, Zinc and Tin-metal complexes.

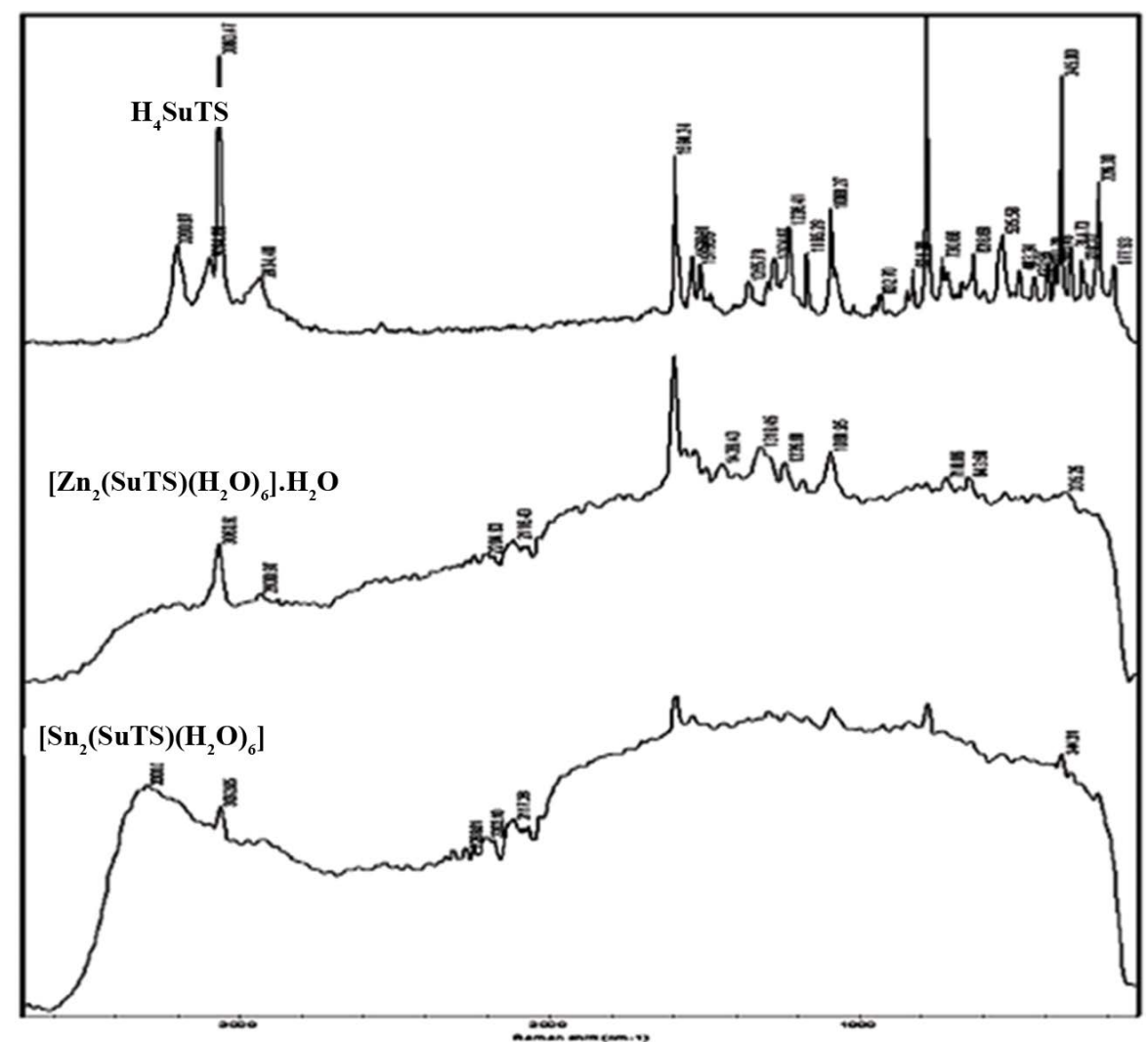

Figure S6. Raman spectra for 1, 1-Oxalaylbis-4phenylthiosemicarbazide, Zinc and Tin-metal complexes. 


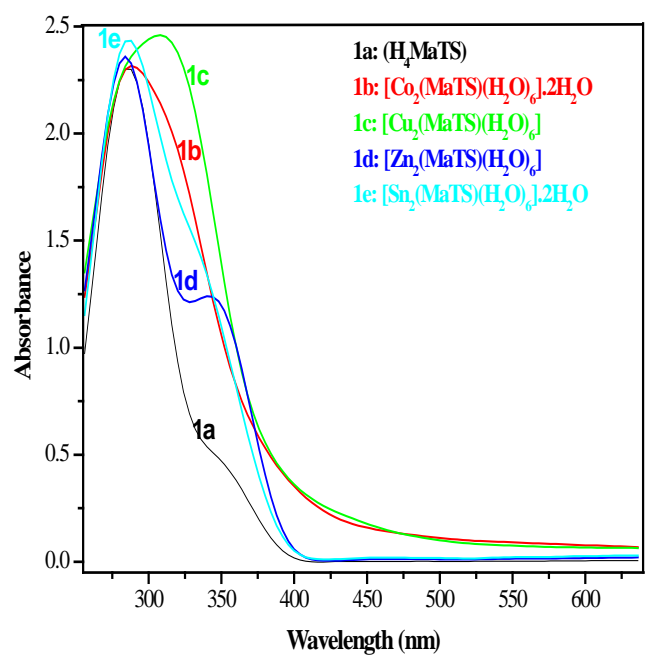

Figure S7. Ultraviolet and Visible spectra diagram of 1,1-Malonyl-bis (4phenyl thiosemicarbazide) and its metal complexes.

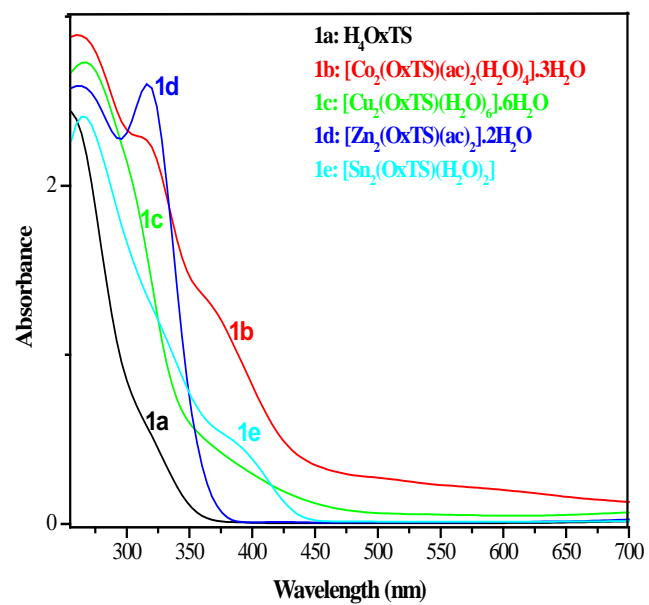

Figure S8. Ultraviolet and Visible spectra diagram of 1,1-Oxalyl-bis (4phenyl thiosemicarbazide) and its metal complexes.

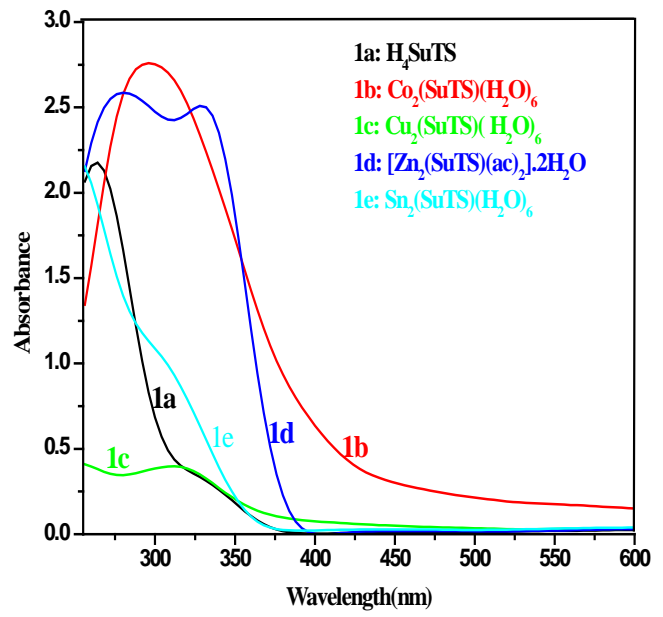

Figure S9. Ultraviolet and Visible spectra diagram of 1,1-Succinyl-bis(4phenyl thiosemicarbazide) and its metal complexes. 

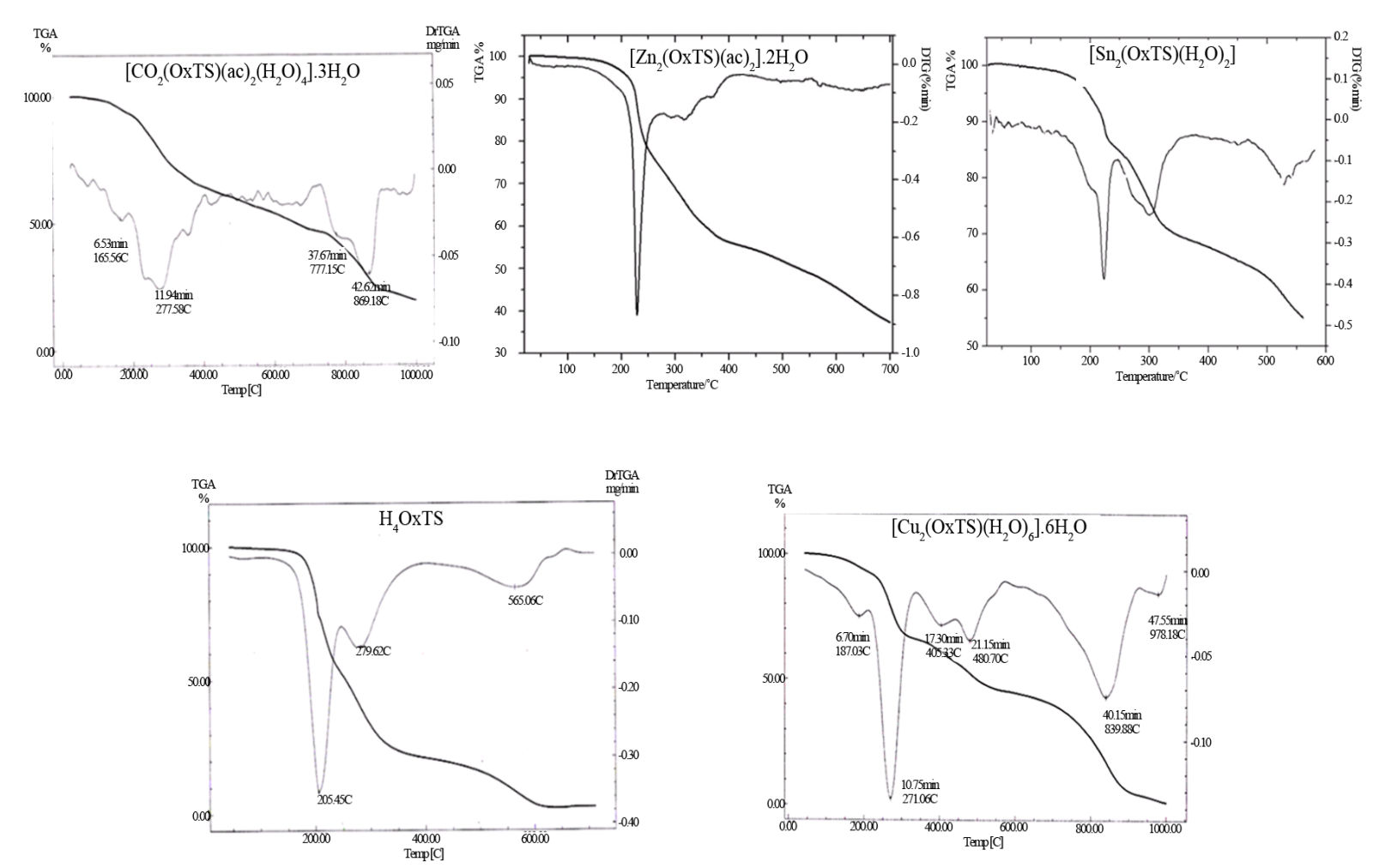

Figure S10. TGA and DTGA diagram of 1,1-oxalyl-bis(4- phenyl thiosemicarbazide), $\mathrm{H}_{4} \mathrm{OxTSC}$ and its metal complexes.
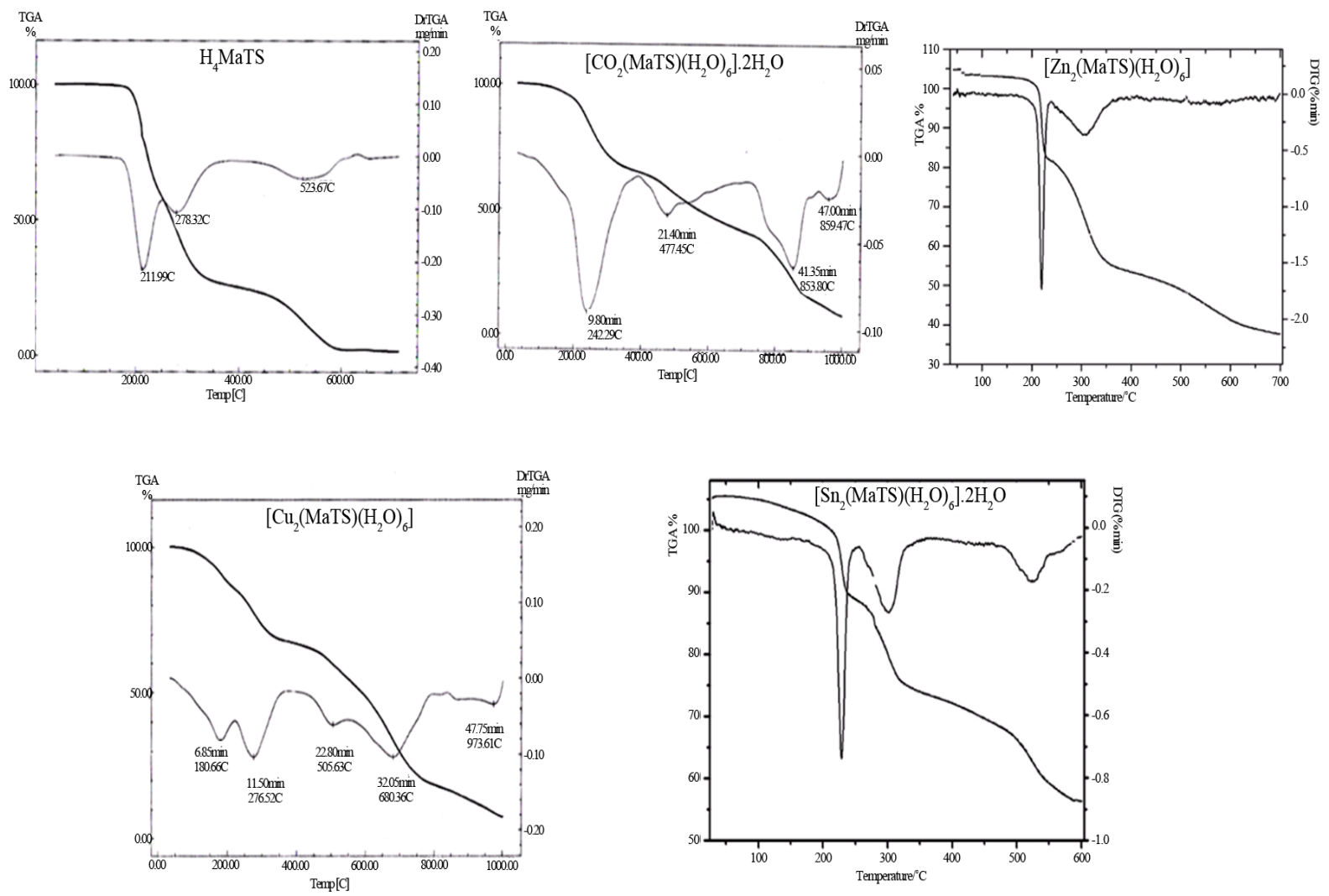

Figure S11. TGA and DTGA diagram of 1,1-malonayl-bis(4-phenyl thiosemicarbazide), $\mathrm{H}_{4}$ MaTSC and its metal complexes. 
R. R. Amin et al.
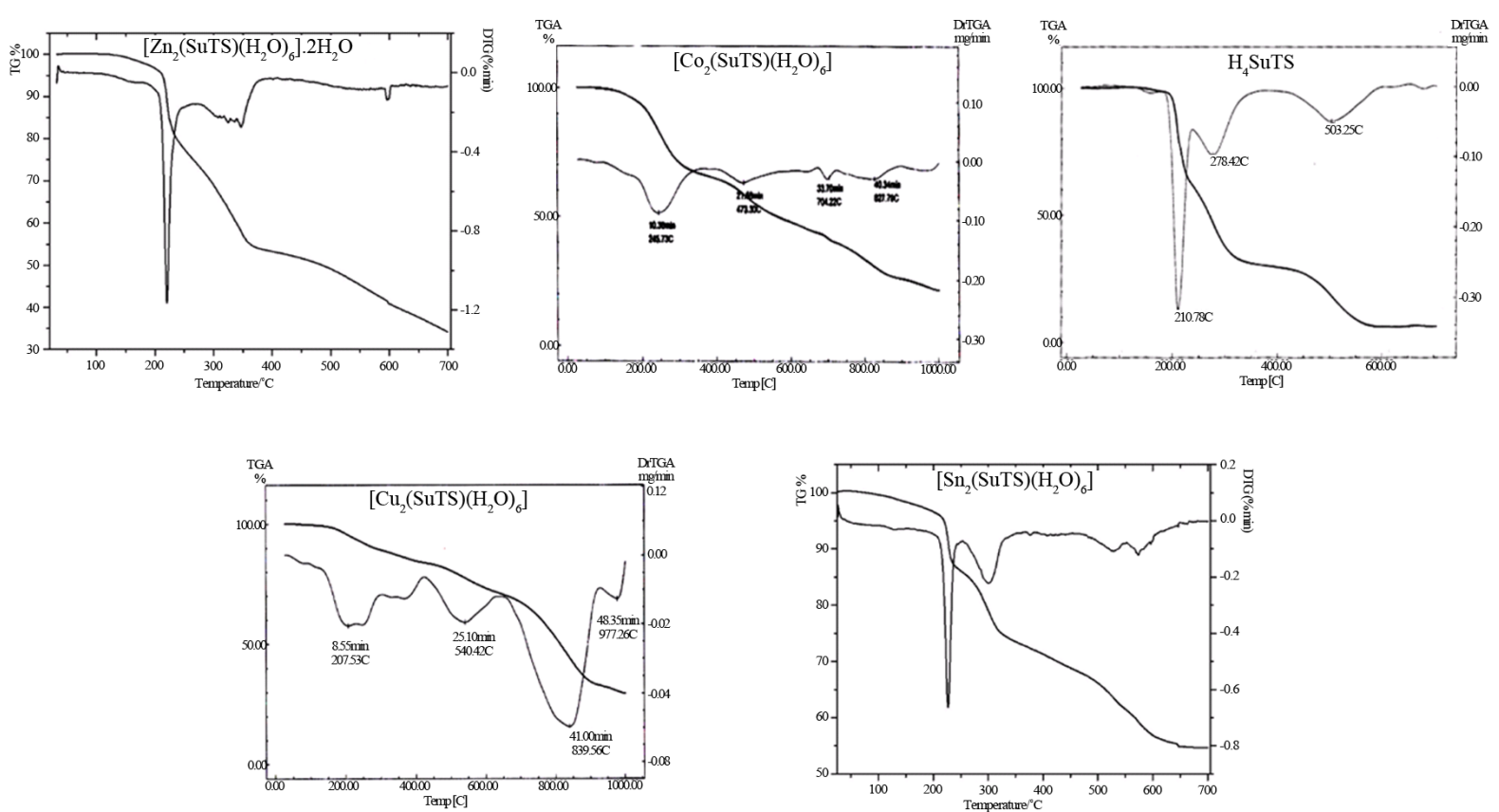

Figure S12. TGA and DTGA diagram of 1,1-succinyl-bis(4- phenyl thiosemicarbazide), $\mathrm{H}_{4} \mathrm{SuTSC}$ and its metal complexes.
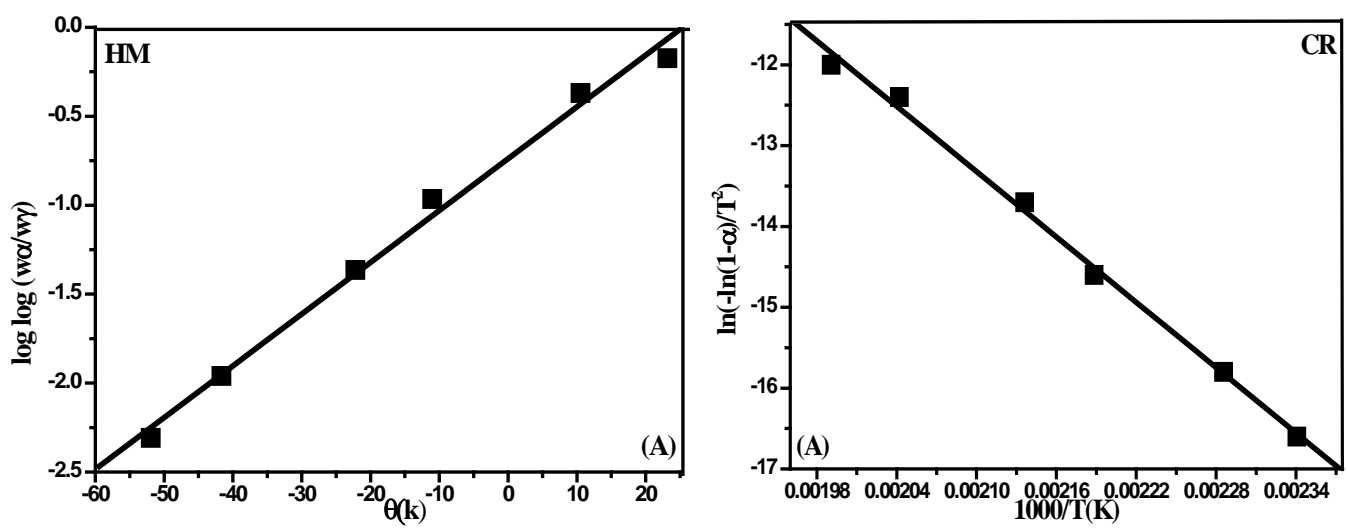

Figure S13. Kinetic data curves of: 1,1-Oxalyl-bis(4-phenyl thiosemicarbazide).
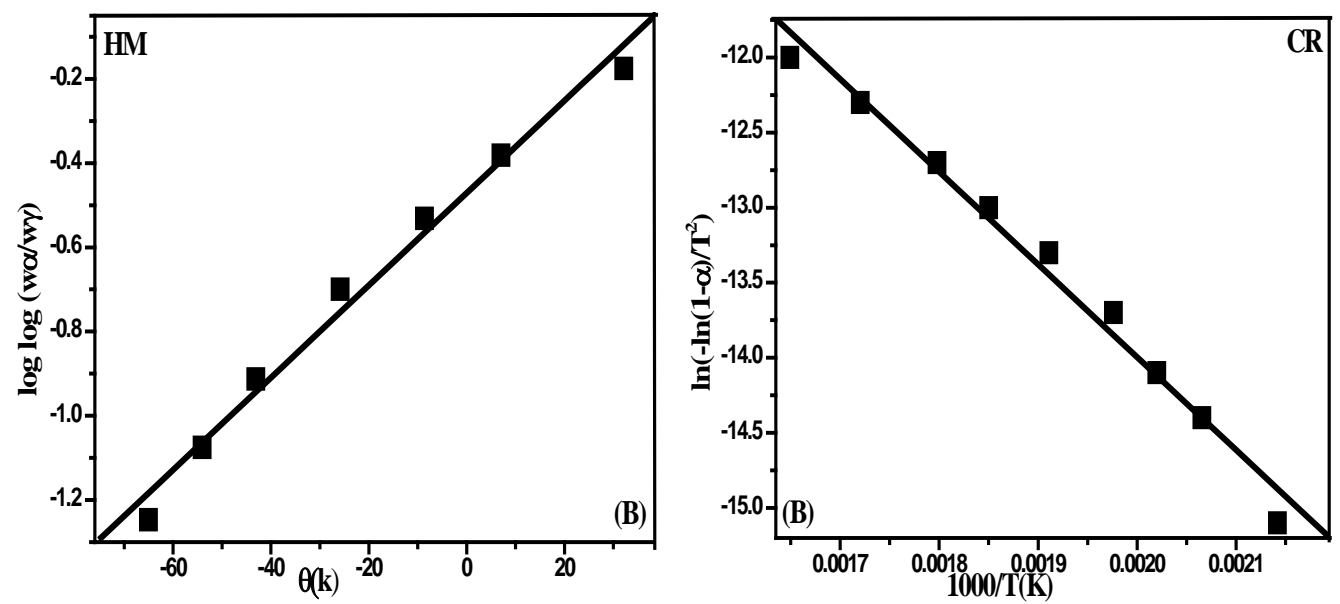

Figure S14. Kinetic data curves of: $\left[\mathrm{Co}_{2} \mathrm{OxTS}(\mathrm{ac})_{2}\left(\mathrm{H}_{2} \mathrm{O}\right)_{4}\right] \cdot 3 \mathrm{H}_{2} \mathrm{O}$ complex. 

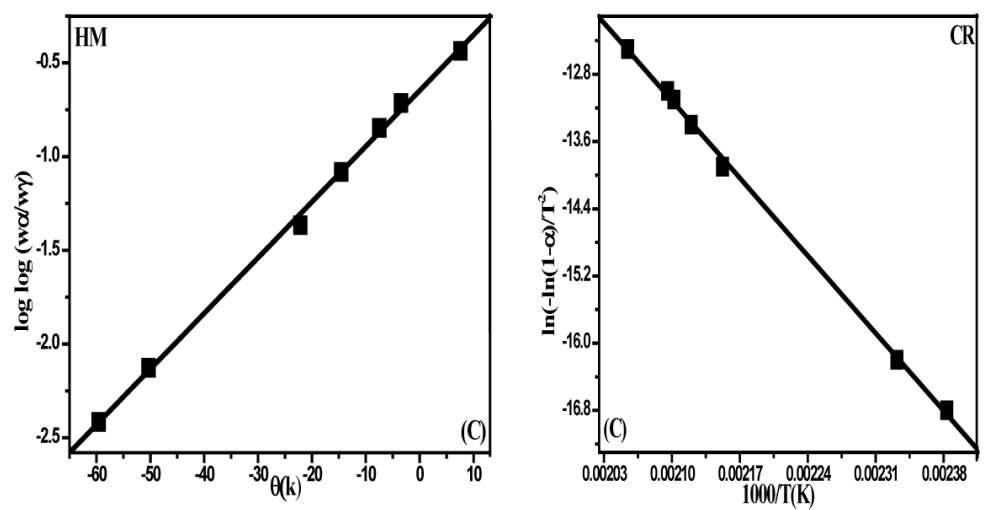

Figure S15. Kinetic data curves of $\left[\mathrm{Cu}_{2} \mathrm{OxTS}\left(\mathrm{H}_{2} \mathrm{O}\right)_{6}\right] \cdot 6 \mathrm{H}_{2} \mathrm{O}$ complex.
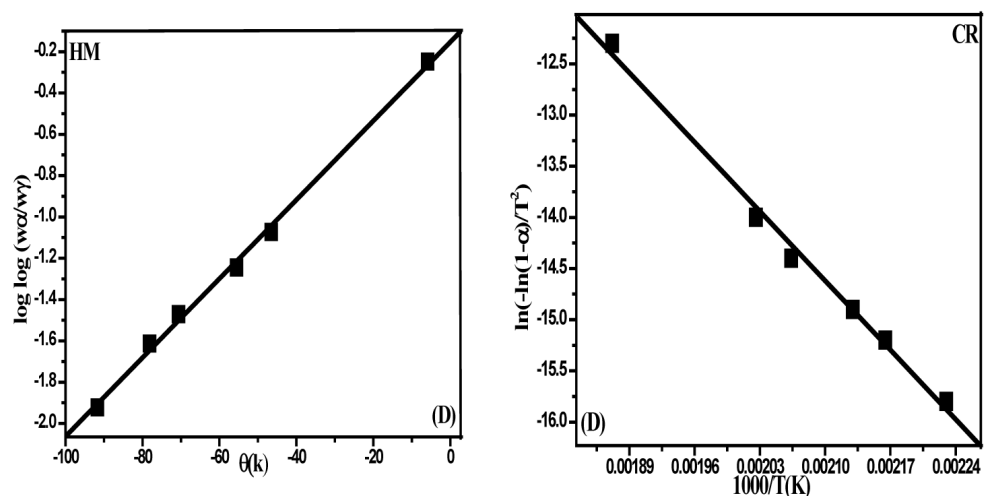

Figure S16. Kinetic data curves of: $\left[\mathrm{Zn}_{2} \mathrm{OxTS}(\mathrm{ac})_{2}\right] \cdot 2 \mathrm{H}_{2} \mathrm{O}$ complex.
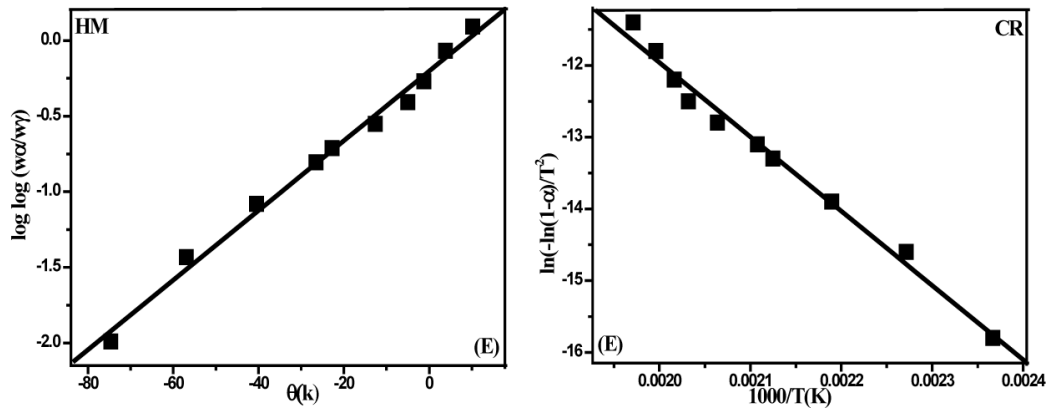

Figure S17. Kinetic data curves of $\left[\mathrm{Sn}_{2} \mathrm{OxTS}\left(\mathrm{H}_{2} \mathrm{O}\right)_{2}\right]$ complex.
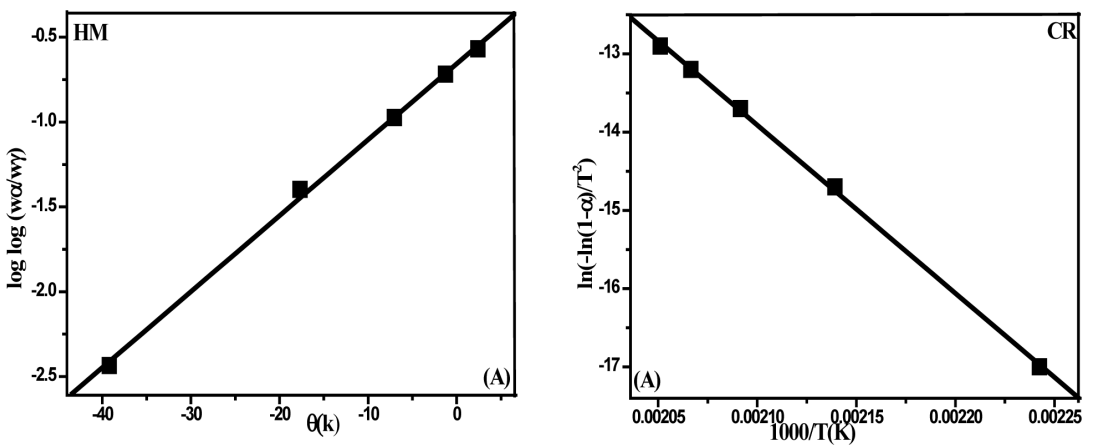

Figure S18. Kinetic data curves of 1,1-Malonayl-bis(4-phenyl thiosemicarbazide). 

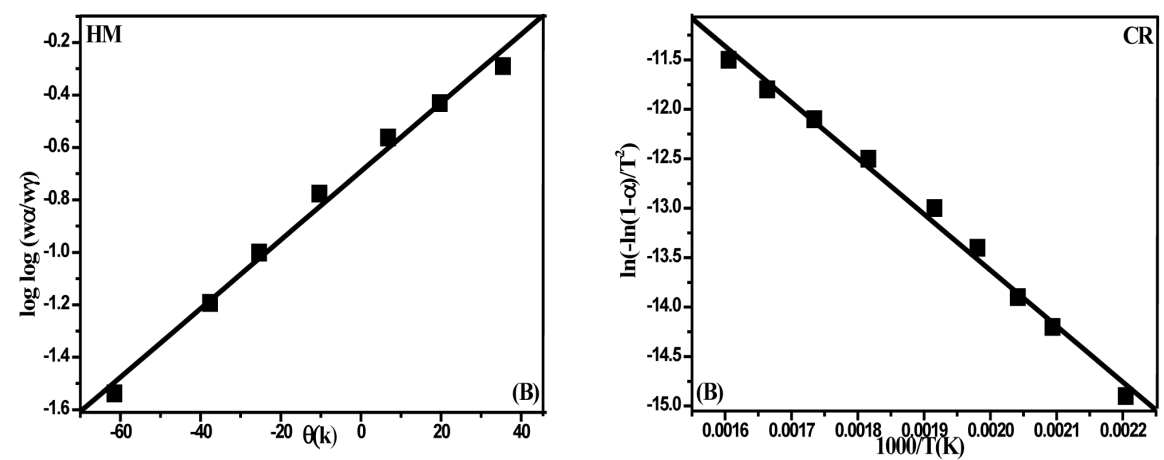

Figure S19. Kinetic data curves of $\left[\mathrm{Co}_{2} \mathrm{MaTS}\left(\mathrm{H}_{2} \mathrm{O}\right)_{6}\right] \cdot 2 \mathrm{H}_{2} \mathrm{O}$ complex.
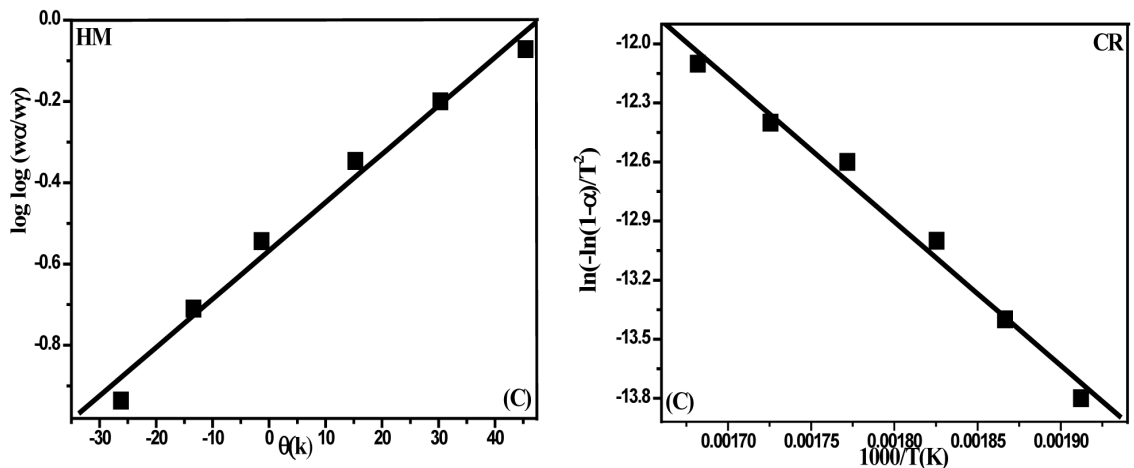

Figure S20. Kinetic data curves of: $\left[\mathrm{Cu}_{2} \mathrm{MaTS}\left(\mathrm{H}_{2} \mathrm{O}\right)_{6}\right]$ complex.
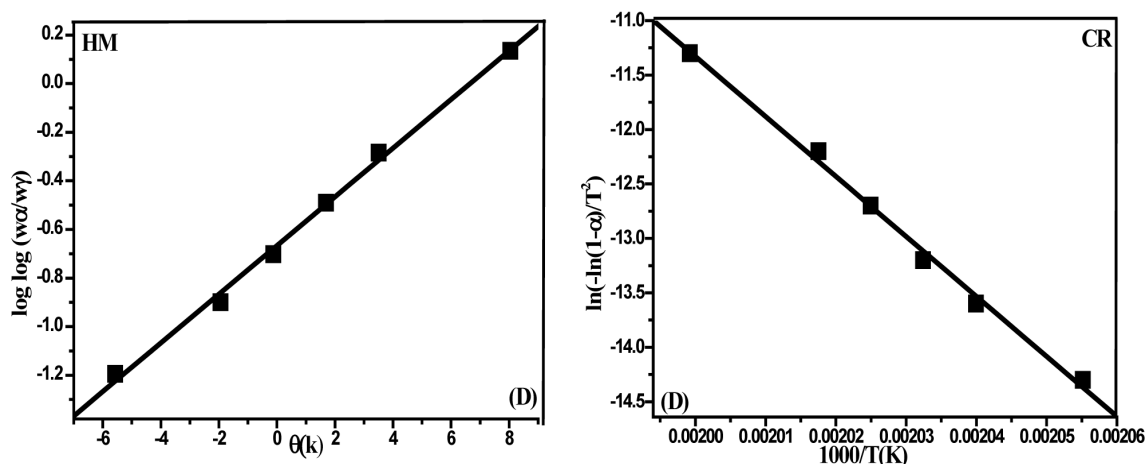

Figure S21. Kinetic data curves of $\left[\mathrm{Zn}_{2} \mathrm{MaTS}\left(\mathrm{H}_{2} \mathrm{O}\right)_{6}\right]$ complex.
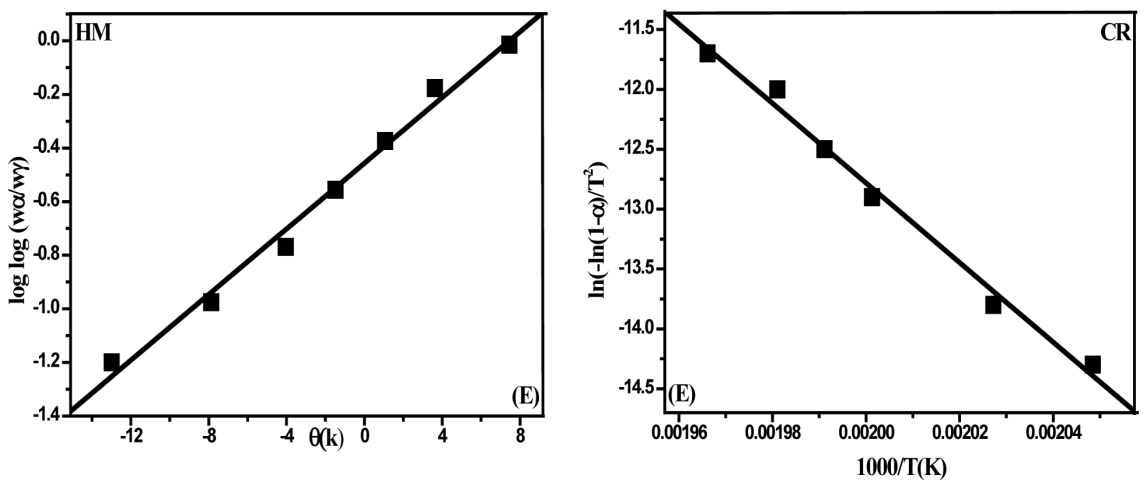

Figure S22. Kinetic data curves of $\left[\mathrm{Sn}_{2} \mathrm{MaTS}\left(\mathrm{H}_{2} \mathrm{O}\right)_{6}\right] \cdot 2 \mathrm{H}_{2} \mathrm{O}$ complex. 

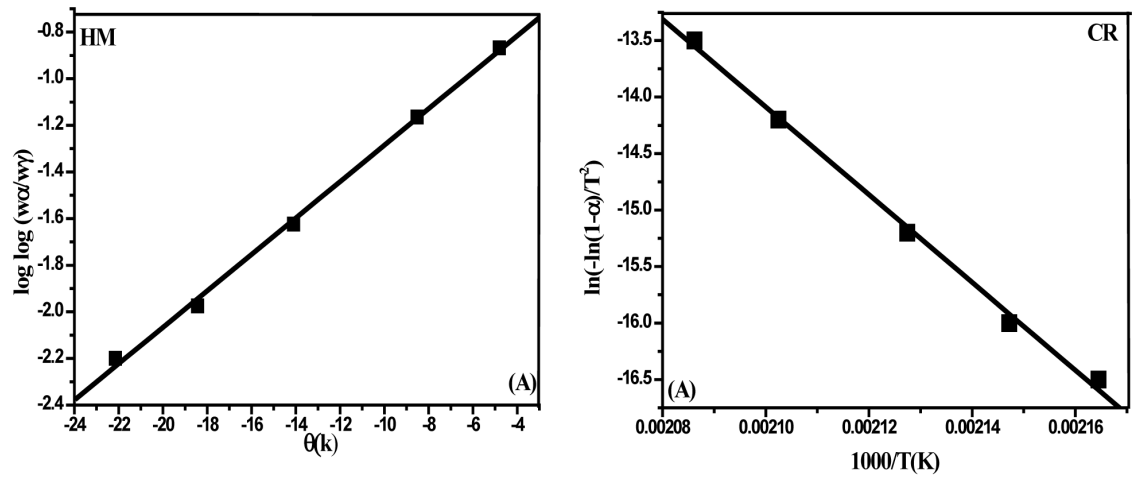

Figure S23. Kinetic data curves of 1,1-Succinyl-bis(4-phenyl thiosemicarbazide).
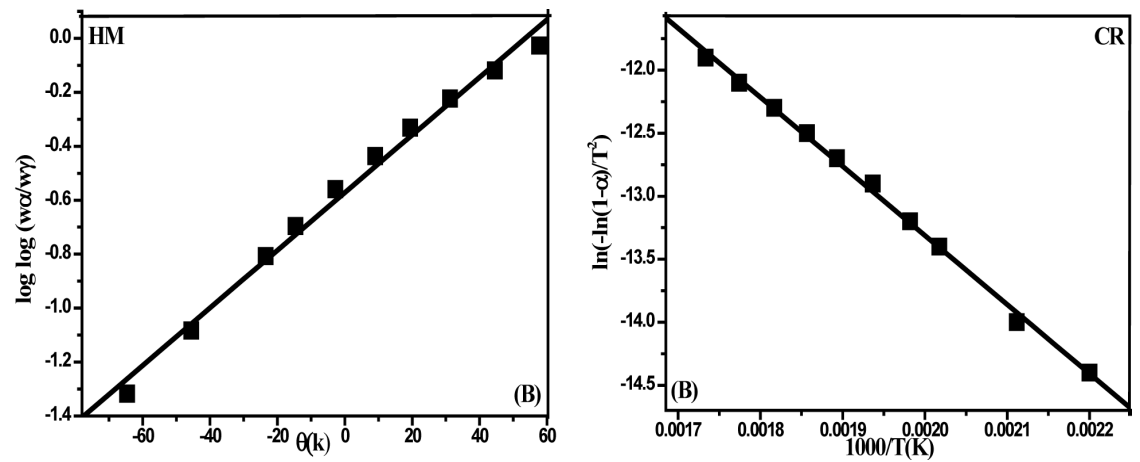

Figure S24. Kinetic data curves of $\left[\mathrm{Co}_{2} \mathrm{SuTS}\left(\mathrm{H}_{2} \mathrm{O}\right)_{6}\right]$ complex.
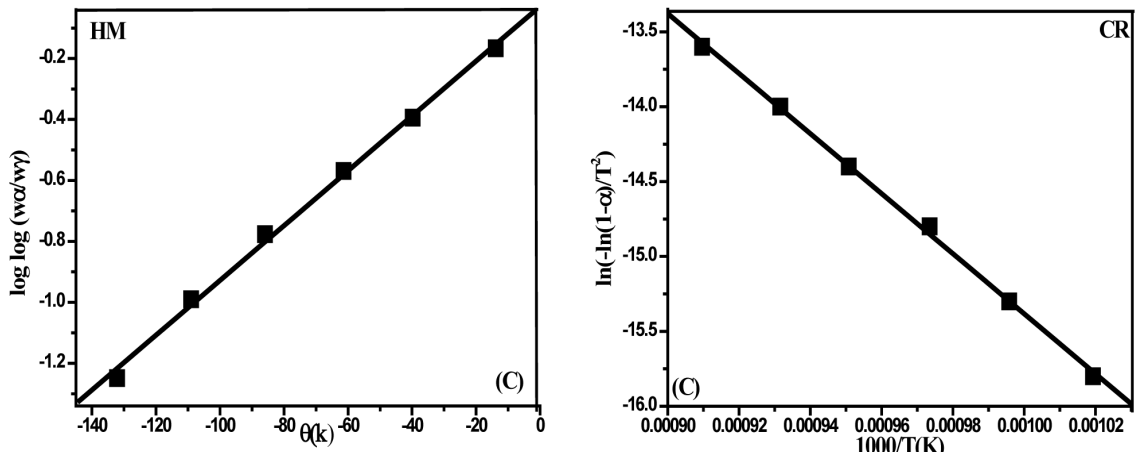

Figure S25. Kinetic data curves of $\left[\mathrm{Cu}_{2} \mathrm{SuTS}\left(\mathrm{H}_{2} \mathrm{O}\right)_{6}\right]$ complex.
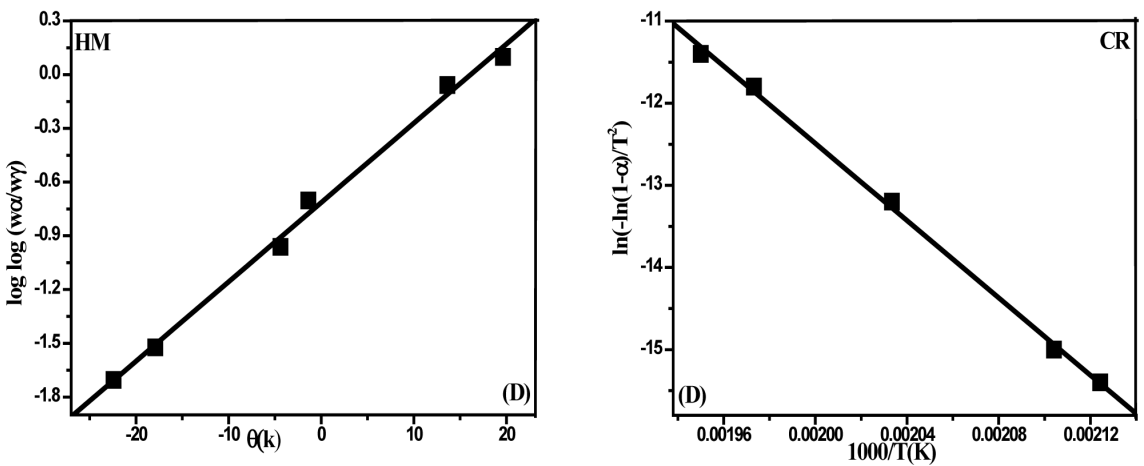

Figure S26. Kinetic data curves of $\left[\mathrm{Zn}_{2} \mathrm{SuTS}(\mathrm{ac})_{2}\right] \cdot 2 \mathrm{H}_{2} \mathrm{O}$ complex. 

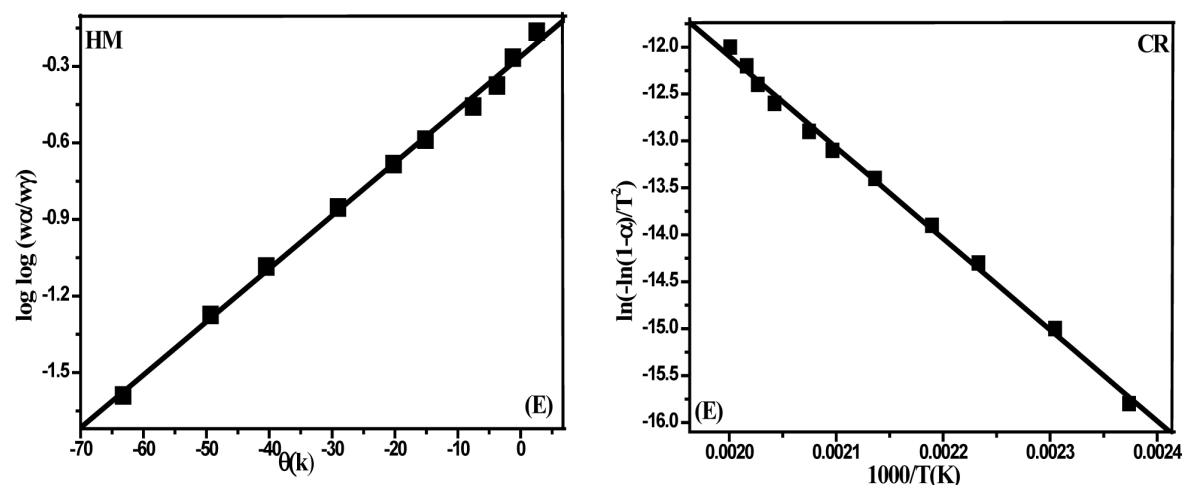

Figure S27. Kinetic data curves of $\left[\mathrm{Sn}_{2} \mathrm{SuTS}\left(\mathrm{H}_{2} \mathrm{O}\right)_{6}\right]$ complex. 